\title{
Organochlorine pesticides in protected areas: El Hito Lake (Cuenca, Central Spain)
}

\author{
Yolanda Sánchez-Palencia ${ }^{1}$ D . José E. Ortiz ${ }^{1}$ Trinidad Torres $^{1}$ • Juan Llamas ${ }^{1}$
}

\begin{abstract}
Background E1 Hito Lake is an ephemeral saline water mass present most of the year as a gypsiferous salt pan that is temporarily flooded during rainy periods, when it becomes a refuge for migratory birds such as flamingos and cranes, among others. It is considered an important hotspot of biodiversity and as such is covered by protection status.

Purpose In order to check the environmental condition of the lake and determine the spatial distribution and source of organochlorine pesticides (OCPs), we performed a detailed soil and sediment sampling campaign with the catchment and dry lake bottom.

Methods We present the first environmental evaluation of its current state with respect to OCPs: hexachlorobenzene (HCB), hexachlorocyclohexanes $(\alpha-, \beta-, \gamma-$ and $\delta$-HCH), dichlorodiphenyltrichloroethane (DDT) and its metabolites (DDE and DDD), and cyclodienes (aldrin, dieldrin, endrin, endrin aldehyde, endrin ketone, $\alpha$-chlordane, $\gamma$-chlordane, endosulfan I, endosulfanII, endosulfan sulphate, heptachlor, heptachlor epoxide B and metoxichlor).

Results Some of the compounds showed concentrations above the soil screening levels (SSLs) for human health and ecosystems: $\gamma$ - $\mathrm{HCH}(100 \mu \mathrm{g} / \mathrm{kg}), \alpha-\mathrm{HCH}(60 \mu \mathrm{g} / \mathrm{kg})$, endrin $(30 \mu \mathrm{g} / \mathrm{kg})$, aldrin $(30 \mu \mathrm{g} / \mathrm{kg})$ and heptachlor epoxide B $(30 \mu \mathrm{g} / \mathrm{kg})$. Various indices were used to determine the origin of the compounds.

Conclusion Historical uses were interpreted, although there were traces of recent input. Distribution maps of concentration and indices demonstrate a relationship between farming and cropping and the maxima observed, being possible that OCPs have influence in living beings, especially birds.
\end{abstract}

Keywords Organochlorine pesticides · Lacustrine sediments $\cdot$ Soil contamination $\cdot$ SSL $\cdot$ POPS

\section{Resumen}

Antecedentes La Laguna de El Hito es un humedal salino y efímero que aparece la mayor parte del año como un salar yesífero en el que se acumula agua durante periodos lluviosos y se convierte en refugio de aves migratorias como flamencos y grullas, entre otros. Se considera un lugar de importancia para la biodiversidad y por ello está protegido por diversas directivas.

Objetivos Se realizó una campaña de muestreo de los suelos de la cuenca y de los sedimentos del fondo de la laguna con el objetivo de conocer su estado ambiental y determinar la distribución espacial y el origen de los pesticidas organoclorados (OCP).

Métodos Se presenta la primera evaluación del estado actual de la laguna respecto a los OCP: hexaclorobenzeno (HCB), hexaclorociclohexanos $(\alpha-, \beta-, \gamma-$ y $\delta$-HCH), diclorodifeniltricloroetano (DDT) y sus metabolitos (DDE y DDD), y los ciclodienos (aldrín, dieldrín, endrín, endrín aldehido, endrín cetona, $\alpha$-clordano, $\gamma$-clordano, endosulfán I, endosulfánII, endosulfán sulfato, heptacloro, heptacloro epóxido B y metoxicloro).

Resultados Algunos compuestos mostraron concentraciones por encima de los Niveles Genéricos de Referencia (NGR) para la salud humana y los ecosistemas: $\gamma-\mathrm{HCH}(100 \mu \mathrm{g} / \mathrm{kg}), \alpha-\mathrm{HCH}(60 \mu \mathrm{g} / \mathrm{kg})$, endrín $(30 \mu \mathrm{g} / \mathrm{kg})$, aldrín $(30 \mu \mathrm{g} / \mathrm{kg})$ y heptacloro epóxido B $(30 \mu \mathrm{g} / \mathrm{kg})$. Se emplearon varios índices para determinar el origen de estos compuestos. 
Conclusiones Se interpretó un uso histórico, aunque en algunos casos con un origen reciente. Los mapas de distribución mostraron la alta correspondencia entre la agricultura y ganadería con máximos observados, siendo posible que los pesticidas tengan influencia nociva en los organismos, especialmente en las aves.

Palabras clave Pesticidas organoclorados $\cdot$ sedimentos lacustres $\cdot$ suelos contaminados $\cdot$ NGR $\cdot$ POP

\section{Introduction}

Organochlorine pesticides (OCPs) are characterized by the presence of chlorine, hydrogen, carbon and occasionally oxygen. Their high stability (resistance to degradation by solar radiation, temperature, humidity and metabolic processes) and partition coefficients (soil-air, water-air, sediment-water, octanol-water) allows these compounds to persist in the environment. In this regard, they can be transported long distances, from populated areas to nearby water bodies and remote tropical, temperate and polar ecosystems, where they bioaccumulate in aquatic food chains and have adverse biological effects), particularly on apex predators (Wania and Mackay 1995, 1999; Wania et al. 1997; Gouin et al. 2000; James et al. 2001; MacDonald et al. 2001; El Nemr et al. 2012; Hu et al. 2014). As a result of the properties of OCPs, the use of these compounds was banned some decades ago.

In 2001, the Stockholm Convention of the United Nations drew up a list of persistent organic pollutants (POPs) that comprises 13 OCPs: aldrin, dieldrin, endrin, chlordane, heptachlor, hexachlorobenzene (HCB), hexachlorocyclohexanes $(\alpha-\mathrm{HCH}, \beta-\mathrm{HCH}, \gamma-\mathrm{HCH})$, endosulfan (I and II), endosulfan sulfate and dichlorodiphenyltrichloroethane and its respective metabolites (DDTs). Most persistent OCPs have been forbidden in Europe and North America, but many are still in use in Africa, Asia, and South America (Fry 1995; FAO 2015).

In Spain, OCPs have traditionally been used in agriculture and they were produced for decades until their prohibition (Morales et al. 2012; Fernández et al. 2013). In this regard, the waste in the landfills at former OCP production sites is a matter of environmental concern due to possible diffuse accumulation, and measures are required for the remediation of such sites (Fernández et al. 2013). Although most OCPs were banned from use in developed countries in the 1970s and 1980s (Mañosa et al. 2001; Guitart et al. 2005), concentrations are still detected in environmental samples (Arienzo et al. 2015; Yang et al. 2015). This presence can be attributed to their persistence, but also to continued use in some developing countries (Mullié et al. 1992; Sanpera et al. 2003; Shunthirasingham et al. 2010).

OCPs enter the environment through agriculture, livestock, water runoff from domestic and industrial facilities, and atmospheric deposition (rainfall). Due to their low water solubility, they are more easily attached to suspended particles, which finally settle on soils. Consequently, these sediments are a secondary source of contamination, as they can release the OCPs into water (bioturbation, drainage, etc.; Gong et al. 2007; Yuan et al. 2013).

El Hito Lake in Central Spain (Fig. 1a) lies in an area that boasts high ecological diversity. Apart from the botanical, faunal and hydrological characteristics of the zone, it is one of the scarce wetlands in the region of Castilla-La Mancha and is protected by several directives: "Lugar de Importancia Comunitaria" UE 1997, "Reserva de la Biosfera de la Mancha Húmeda" Unesco 1981, "Reserva Natural" Junta de Castilla la Mancha (DOCM 26/2003), Directiva 79/409/CEE and 92/43/CEE and RAMSAR site Spain 3ES043. In fact it is a refuge for migratory birds, such as flamingos and cranes.

In this regard, many studies attest the environmental damage caused by OCPs, especially in birds, since there is evidence that they are deficient in certain enzymes that enhance the detoxification of pesticides (Walker 1983). As some studies report (Rudd and Herman 1972; Gilman et al. 1979), DDD was used to control gnats in Clear Lake, California; this was the first well-documented ecological magnification of these pesticides in invertebrates, fishes, and birds (Fry 1995). Moreover, from 1946 to 1948 there was a general introduction of DDT and $\gamma-\mathrm{HCH}$ in domestic and agricultural practises, which coincided with the onset of eggshell changes in birds (Ratcliffe 1970). Eggs have been used as bioindicators of these compounds since they reflect the total body concentration in the laying bird (Furness 1993; Mateo et al. 2004). Other potential harmful effects on birds are: acute mortality, sublethal stress, reduced fertility, decreased parental attentiveness, reduced territorial defence, weight loss, lethargic behavior, suppressed immune system response, interference with body temperature regulation, disruption of normal hormonal function, and inability to orient in the proper direction for migration (Gilman et al. 1979; Ratcliffe 1970; Deinlein 1998). Also, OCPs can cause the following to embryos: mortality, deformations, reduced hatchability, failure of chicks to thrive, and teratological effects that cause skeletal abnormalities and impaired differentiation of the reproductive and nervous systems (Peakall 1970; Fry 1995; Deinlein 1998).

A direct route of exposure can be via ingestion: birds or mammals with a diet consisting mainly of worms caught in polluted agricultural land or soil to which a pesticide has been applied, also diets based on crops, insects, treated seeds or water (van Leeuwen and Hermens 1995; Newton 1995; 
(a)

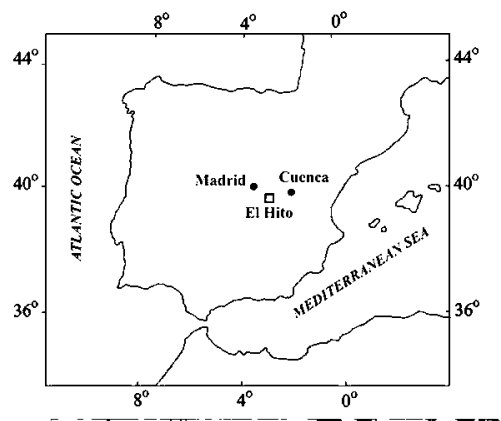

(c)

(d)

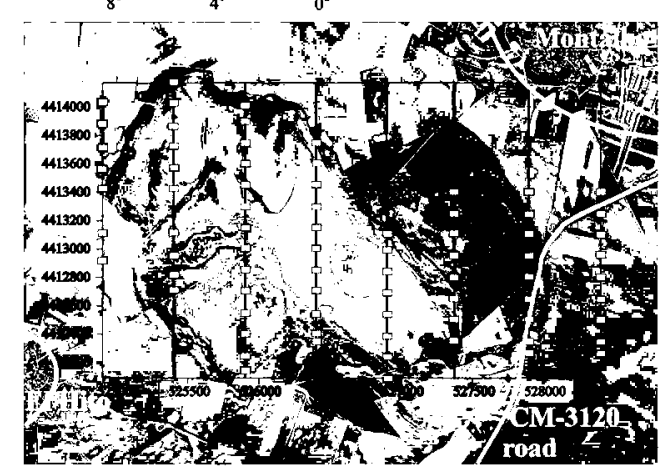

(b)

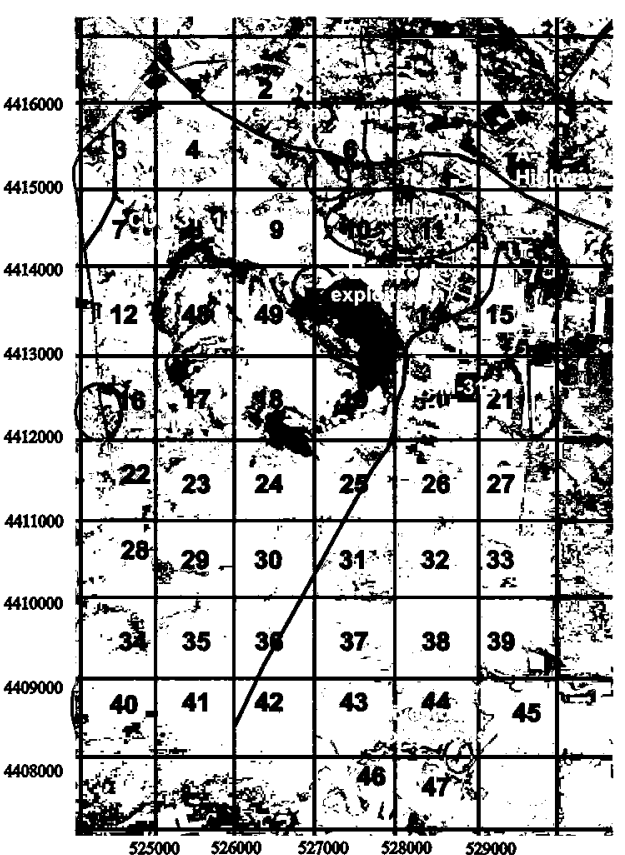

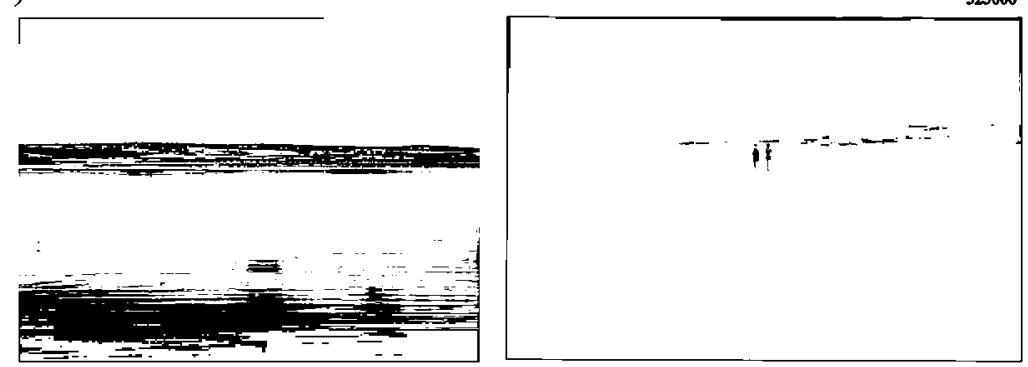

Fig. 1 a Geographical location of $\mathrm{E} 1$ Hito Lake; $\mathbf{b}$ lake catchment with the grid $(1 \times 1 \mathrm{~km})$ where the samples were collected; $\mathbf{c}$ lake area together with the eight $\mathrm{N}-\mathrm{S}$ transects defined for collecting the samples; $\mathbf{d}$ the lake during the humid and dry seasons

Deinlein 1998). Indirectly, OCPs can be taken up through bathing in tainted water, inhalation, or ingestion while preening (Deinlein 1998). The pesticides also affect the soil killing organisms such as bacteria, fungi and algae, which break down plant residues to release minerals, carbon, and nitrogen. Moreover, they affect insect populations, which break down plant matter into new soil, and earthworms, which aerate the soil and serve as nutriment for birds. Consequently, OCPs can degrade soil to the extent that it cannot serve for agricultural purposes.

Concentrations of OCPs have been detected in birds and eggs (Peakall 1970; González et al. 1991; Piqué et al. 2006; Luzardo et al. 2014), particularly in greater flamingo eggs in the National Park of Doñana (Spain), as reported Guitart et al. (2005), although damage in these birds was not reported. The published studies using birds in Spanish wetlands reveal a persistent medium impact of OCPs in this country, thereby emphasizing the need for stricter controls to reduce the release of these pollutants into the environment, especially into aquatic systems (Mañosa et al. 2001; Sanpera et al. 2003; Guitart et al. 2005).

Given the damage that OCPs cause, measures should be taken to evaluate the sources of pollution and to minimize their impact, especially in protected species and areas, like El Hito. In this regard, international collaboration is crucial to protect migratory birds since they travel long distances (Newton 1995; Morales et al. 2012).

In order to provide a detailed and reliable study of OCPs, we analysed not only sediments from the lake but also from its catchment area. With the exception of a narrow strip of saline steppe preserved around the edge of the lake, the catchment comprises mainly cultivated land, where pesticides have been and continue to be used, some livestock exploitation, and villages (Montalbo and El Hito; Fig. 1b). The lake therefore serves as a recipient and accumulator of contaminants transported by both water and air.

Therefore, here we checked the environmental condition of El Hito Lake and catchment through a detailed soil 
and sediment sampling campaign. To this end, we did the following:

- Performed the first environmental evaluation of its current state with respect to OCPs: hexachlorobenzene (HCB), hexachlorocyclohexanes ( $\alpha-, \beta-, \gamma$ - and $\delta-\mathrm{HCH})$, dichlorodiphenyltrichloroethane and its metabolites (DDE and DDD), and cyclodienes (aldrin, dieldrin, endrin, endrin aldehyde, endrin ketone, $\alpha$-chlordane, $\gamma$-chlordane, endosulfan I, endosulfan II, endosulfan sulphate, heptachlor, heptachlor epoxide B and metoxichlor).

- Evaluated the contamination of sediments and soils by comparing the abundance of OCPs with the soil screening levels (SSLs) for human health and ecosystems.

- Assessed the spatial distribution of OCP contamination in the lake sediments and in the catchment, in order to identify possible waste sources and to define the baseline.

- Determined the source and degradation state of the compounds using molecular indices based on the ratios of the concentration of individual OCPs in sediment, namely $\alpha-\mathrm{HCH} / \gamma-\mathrm{HCH}$ (Zhang et al. 2004), $\beta-\mathrm{HCH} /(\alpha+\gamma)$ HCH (Liu et al. 2012), (DDE + DDD)/ DDDT (Hitch and Day 1992), $\gamma$-/ $\alpha$-chlordane (Bidleman et al. 2002), $o, p^{\prime}-1 p, p^{\prime}$-DDT (Qiu et al. 2005), $\alpha$ - $/ \gamma$-endosulfan (Jiang et al. 2009) and $\Sigma$ HCHs/LDDTs (Gao et al. 2013).

\section{Site description}

With an area of 350 ha, El Hito Lake is located in the province of Cuenca in Central Spain (Fig. 1), between the municipalities of El Hito and Montalbo. It lies in an endorheic depression with a catchment of $48 \mathrm{~km}^{2}$ and it is characterized by being a saline and ephemeral water body. Consequently, it dries up for some months, mainly from July to November (Fig. 1d). During the humid period it shows wide ecological diversity, serving as a stopover for migrating birds. The water level depends on rainfall and groundwater flow, and varies between $1.5 \mathrm{~m}$ deep at the end of summer, and $0.3-0 \mathrm{~m}$ in winter (Sastre et al. 2008).

The lake developed on eroded gypsiferous and lutitic rocks of lower Miocene age that formed the bulk of an alluvial-lacustrine infill of this continental Neogene basin (Depresión Intermedia Basin). This small catchment is related to a karst form, a poljé, linked to a fault that contributes to the Montalbo cliff definition. Some small dolines at the lake bottom confirm its karstic origin. Surface runoff plays a decisive role in water input to the lake, although diffuse input from groundwater cannot be discarded.

El Hito is characterised by high ecological diversity, including several fauna and flora species. However, no fish are present as it is an ephemeral lake. Several endangered species have been reported living in the area, among mammals (Palomo and Gisbert 2002): Erinaceus europaeus (common hedgehog), Talpa occidentalis (iberian mole) and Mustela nivalis (least weasel). The most interesting fauna are the wintering nesting aquatic bird communities (Madroño et al. 2004): Anas crecca (common teal), Anas acuta (northern pintail), and Anas clypeata (northern shoveller), and occasionally Tadorna tadorna (common shelduck), Anas strepera (gadwall), Anas platyrhynchos (mallard), and Aythya ferina (common pochard), among others. There are migratory path concentrations of Phoenicopterus roseus (greater flamingo), Grus grus (common crane), as well as Himantopus himantopus (common stilt), Recurvirostra avosetta (pied avocet), Vanellus vanellus (northern lapwing), Platalea leucorodia (common spoonbill), Anas querquedula (garganey), and Gallinago gallinago (common snipe). Some ostracode species appear (Eucypris salina).

A variety of steppe plants of halophytic character are associated with the lake (Cirujano 1995; Cirujano et al. 2002), such as Puccinellia fasciculate, Salicornia ramosissima, Frankenia laevis, Aelinopuslitoralis, Lygeum sportum, Limonium spp, Gypsophila bermejoi, Microcnemum coraloides, Schoenas nigicans, Iris xiphium, Aeloropus littoralis, Spergularia media, and Salicornia ramosissima; aquatic machophytes: Scirpus maritimus, and Ranunculus aquatilis; and algae: Tolypella salina, Chara canescens, Tolypella hispanica, Chara galioides, and Ruppia drepanensis. The catchment holds a relic of former denser vegetation remains, with scattered Pinus sp. and Quercus coccifera.

\section{Materials and methods}

\subsection{Sample collection}

We collected samples during two campaigns: one for the catchment sediments and the second for the lake sediments. Catchment samples were collected using a $1 \times 1 \mathrm{~km}$ grid (Fig. 1b). The samples were composed of four subsamples of $1 \mathrm{~kg}$, which were taken with a helicoidal soil auger in the central point of each grid. Finally, these subsamples were mixed and quartered until a final weight of $1 \mathrm{~kg}$, thus resulting in a total of 50 samples. Later in the laboratory, these samples were dry-sieved, and the fraction $<0.25 \mathrm{~mm}$ was used for analysis.

The sampling campaign on the dry lake floor was planned on the basis of eight $\mathrm{N}-\mathrm{S}$ transects, $500 \mathrm{~m}$ apart and with a $150 \mathrm{~m}$ sampling interval (from eight to fourteen points) for each transect, resulting in a total of 77 samples (Fig. 1c). 


\subsection{OCP extraction}

OCPs were extracted following EPA method 3545 (EPA 1998), in which it is indicated that the extraction of OCPs is most effective on dry sediment $(5 \mathrm{~g})$ with a small particle size and therefore samples may be ground to a fine powder. Although the EPA protocol accepts a grain size of $<1 \mathrm{~mm}$, after the granulometrical analysis and study of the samples under a microscope, we selected a size cut-off at $0.25 \mathrm{~mm}$ in order to avoid excessive dilution. OCPs were extracted in an accelerated solvent extractor (Dionex ASE 200) with 1:1 hexane/ $\mathrm{Me}_{2} \mathrm{CO}$ at $2000 \mathrm{psi}$ and $100{ }^{\circ} \mathrm{C}$. The heating phase and static extraction time were both $5 \mathrm{~min}$. Prior to extraction, two surrogate standards (200 $\mu \mathrm{l}$ of $10 \mu \mathrm{g} / 1$ tetrachloro- $m$-xylene and decafluorobiphenyl) were added to the samples to check its effectiveness (resulting a final concentration of $0.4 \mu \mathrm{g} / \mathrm{l}$ ). Each extract was concentrated using a rotary evaporator and a TurboVap II concentrator under $\mathrm{N}_{2}$. A solvent change to EtOAc was performed. Also, to test the reliability of the extractions, we used control samples consisting of $5 \mathrm{~g}$ silica sand with a concentration of $1 \mu \mathrm{g} / \mathrm{l}$ of the different pesticides. OCP recoveries were above $80 \%$.

\subsection{OCP analysis}

Each extract was analysed following EPA method 8270 using gas chromatography-mass spectrometry (GC-MS; Agilent-7890/Agilent-5975a mass selective detector and PTV injection ( $90-275^{\circ} \mathrm{C}$ in $\left.0.5 \mathrm{~min}\right)$. OCPs were eluted using a DBS-5MS column $(0.25 \mathrm{~mm} \times 30 \mathrm{~m} \times 0.25 \mu \mathrm{m})$ and $\mathrm{He}$ as carrier gas. The oven temperature was programmed from 60 to $300{ }^{\circ} \mathrm{C}$ (held $10 \mathrm{~min}$ ) at $5{ }^{\circ} \mathrm{C} / \mathrm{min}$ and the injector was at $275^{\circ} \mathrm{C}$. Prior to analysis, an internal standard (50 $\mu 1$ of $10 \mu \mathrm{g} / 1$ pentachloronitrobenzene) was added to the extracts (resulting in a final concentration of $0.5 \mu \mathrm{g} / \mathrm{l}$ ). 21 OCPs: hexachlorobenzene (HCB), hexachlorocyclohexanes $(\alpha-, \beta-, \gamma$ - and $\delta$-HCH), dichlorodiphenyltrichloroethane and its metabolites (DDE and DDD), and cyclodienes (aldrin, dieldrin, endrin, endrin aldehyde, endrin ketone, $\alpha$-chlordane, $\gamma$-chlordane, endosulfan I, endosulfan II, endosulfan sulphate, heptachlor, heptachlor epoxide B and metoxichlor) were assigned by comparing retention times with standards and on the basis of their characteristic $\mathrm{m} / \mathrm{z}$ values and were quantified using peak area integration with the Data Analysis programme and the Wiley Library. To test the effectiveness of the analysis, we run one blank after six samples. For OCP quantification, we ran five standards (containing all the OCPs) with concentrations between 0.05 and $2 \mu \mathrm{g} / \mathrm{l}$, which we used to calculate a calibration curve. The standard relative deviation of the calibration curve was $<20 \%$ for all OCPs.

\section{Results}

The concentration of each OCP was calculated from the calibration curve calculated after the analysis of standards made of OCPs of known concentrations. Results are presented considering the groups of OCPs, namely HCHs, DDTs and cyclodienes, since the properties and behaviour of these groups differ. To represent the compounds in distribution maps, we used the kriging interpolation method run with Surfer 10 software, with the following characteristics, gridding method: kriging, the kriging type: point; the polynomial drift order: 0 ; grid size: 60 rows $\times 100$ columns.

\subsection{Concentration and distribution of OCPs in the lake}

There were significant differences between the abundance of HCHs, DDTs and cyclodienes. Cyclodienes were the most ubiquitous, followed by HCHs and DDTs. The mean OCPs concentration was $57 \mu \mathrm{g} / \mathrm{kg}$, ranging from 2 to $210 \mu \mathrm{g} / \mathrm{kg}$. From the distribution map of total OCPs (Fig. 2a), the highest concentration values were in the southern part of the lake, reaching $200 \mu \mathrm{g} / \mathrm{kg}$ in two samples, although some maxima were registered in other areas.

\subsection{1 $\mathrm{HCHs}$}

The total concentration of HCHs (sum of the $\alpha-, \beta-, \gamma$ - and $\delta$ - isomers) ranged from 0.1 to $150 \mu \mathrm{g} / \mathrm{kg}$ and accounted for $45.6 \%$ of all pesticides in the lake. $\gamma-\mathrm{HCH}$ was the most abundant $(36.1 \%) \mathbf{H C H}$, followed by $\alpha-\mathrm{HCH}(33.4 \%)$, the most carcinogenic according to Doong et al. (2002) and then $\delta-\mathrm{HCH}$ (23.2\%) and $\beta-\mathrm{HCH}(7.2 \%)$. Of the total pesticides, the most abundant were $\alpha-\mathrm{HCH}$ and $\gamma-\mathrm{HCH}$, which accounted for 15.2 and $16.5 \%$, respectively. Li (1999) estimated the usage of HCHs in Spain in recent decades: in 1950 from 100 to $1000 \mathrm{ton} / \mathrm{yr}$ were used, in 1960 from 1000 to 10,000 ton/yr, in 1970 from 10 to 100 ton/yr, and in 1980 and 1990 from 1000 to 10,000 ton/yr. This trend could explain why $\alpha-\mathrm{HCH}$ and $\gamma$-HCH were the most abundant pesticides in the lake.

The distribution of $\mathbf{H C H s}$ in the lake was irregular. Many maxima were observed, the most marked in the southern half (Fig. 2b), one of them near El Hito village. Also, there were significant values in the northwest. The lowest values appeared in the eastern area.

$\mathrm{HCB}$, which is analogous to $\mathrm{HCHs}$, had a concentration of ca. $0.1 \mu \mathrm{g} / \mathrm{kg}$, accounting for $1.1 \%$ of total pesticides.

\subsubsection{DDTs}

The total concentration of DDTs (sum of $p, p^{\prime}$-DDD, $p, p^{\prime}$ DDE and $p, p^{\prime}$-DDT) ranged from $5.84 \times 10^{-2}$ to $16 \mu \mathrm{g} / \mathrm{kg}$ 
(a) $\Sigma 0 C P s$

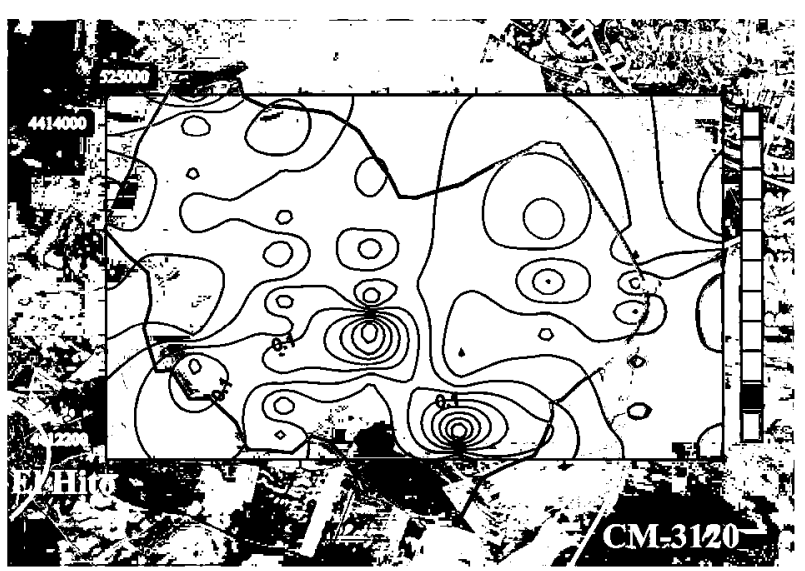

(c) EDDTs

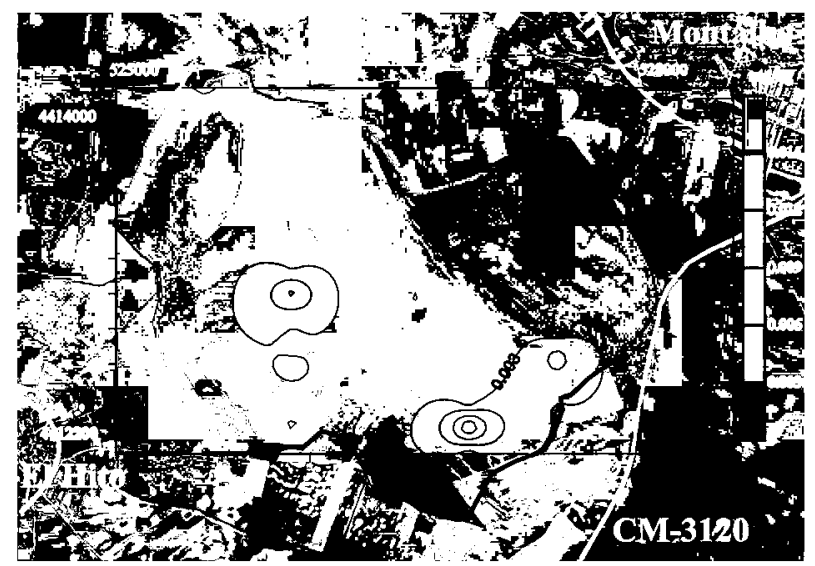

(b) $\mathrm{\Sigma HCHs}$

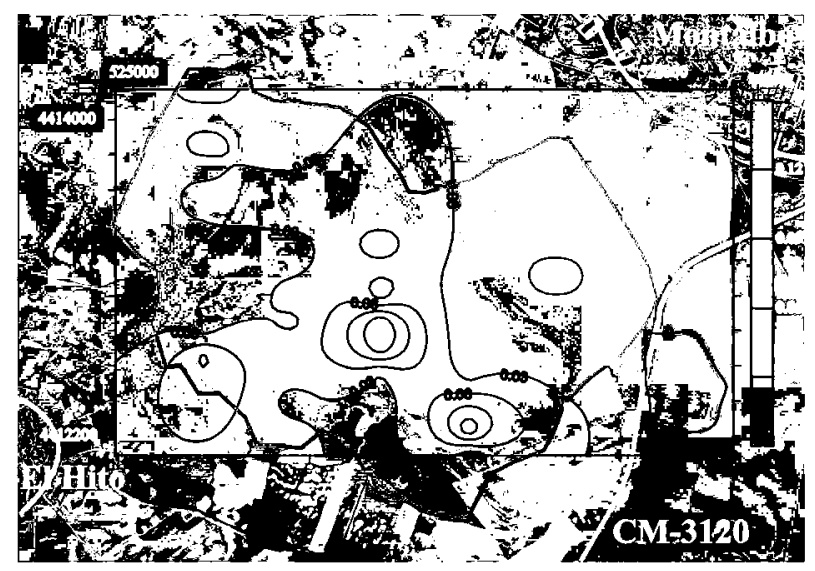

(d) ECyclodienes

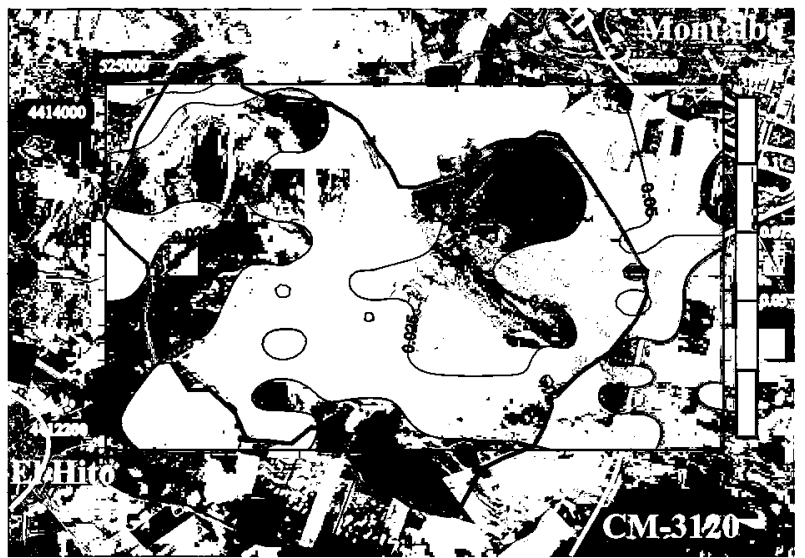

Fig. 2 Distribution maps for the lake of a sum of concentrations of OCPs; $\mathbf{b}$ HCHs; $\mathbf{c}$ DDTs; $\mathbf{d}$ cyclodienes

and accounted for $3 \%$ of total pesticides. $p, p^{\prime}$-DDE and $p, p^{\prime}$ DDD were present in almost the same proportion (38.9 and $38.6 \%$ ) of total DDTs. $p, p^{\prime}$-DDT was detected in $54.5 \%$ of the samples and accounted for $22.5 \%$ of DDTs. The highest concentrations of DDTs were in the southern half of the lake, with some maxima, while the lowest ones were in the central part of the lake (Fig. 2c).

\subsubsection{Cyclodienes}

The total concentration of cyclodienes (sum of heptachlor, heptachlor epoxide $\mathrm{B}$, aldrin, dieldrin, endrin, endrin aldehyde, endrin ketone, $\gamma$-chlordane, $\alpha$-chlordane, endosulfan I, endosulfan II, endosulfan sulfate and metoxichlor) ranged from 0.7 to $73 \mu \mathrm{g} / \mathrm{kg}$, accounting for $50.3 \%$ of total pesticides. Endrin aldehyde was the most abundant, accounting for $21.6 \%$ of cyclodienes, followed by aldrin (15.7\%), heptachlor epoxide B (12.5\%), endrin (12.2\%) and endosulfan I (12\%). Other cyclodienes accounted for $<10 \%$ each.
High concentrations of cyclodienes were occurred in the northeast zone, next to the CM-3120 road and Montalbo village, and in the northwest corner (Fig. 2d). In the central part remarkable local maxima and minima were detected.

\subsection{Concentration and distribution of OCPs in the catchment}

Significant differences were observed between the abundance of HCHs, DDTs and cyclodienes, which were the most abundant contaminants, followed by HCHs and DDTs, as in the lake. The mean OCPs concentration was $39 \mu \mathrm{g} / \mathrm{kg}$, ranging in the samples from 5 to $130 \mu \mathrm{g} / \mathrm{kg}$. In the distribution map of total OCPs (Fig. 3a), the lake attracted contaminants since the maximum value $(86 \mu \mathrm{g} /$ $\mathrm{kg}$ ) was recorded there. Some maxima (130 and $80 \mu \mathrm{g} / \mathrm{kg}$ being the highest) were detected in the south of the catchment, next to two farms. 
(a) $\operatorname{soCPs}$

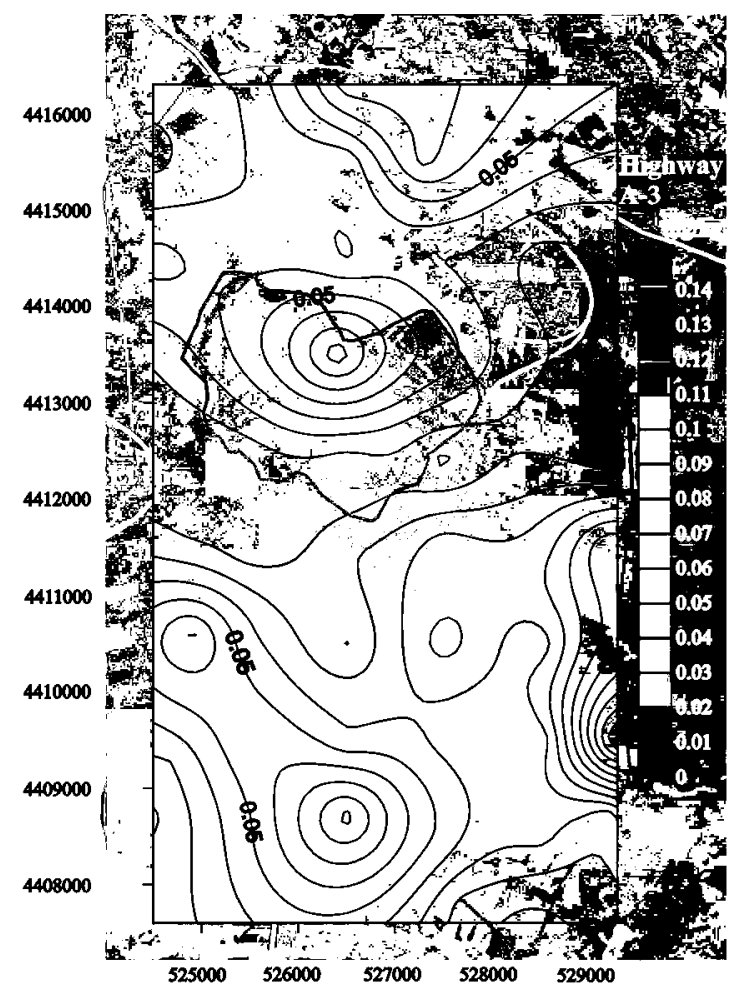

(c) $\Sigma$ DDTs

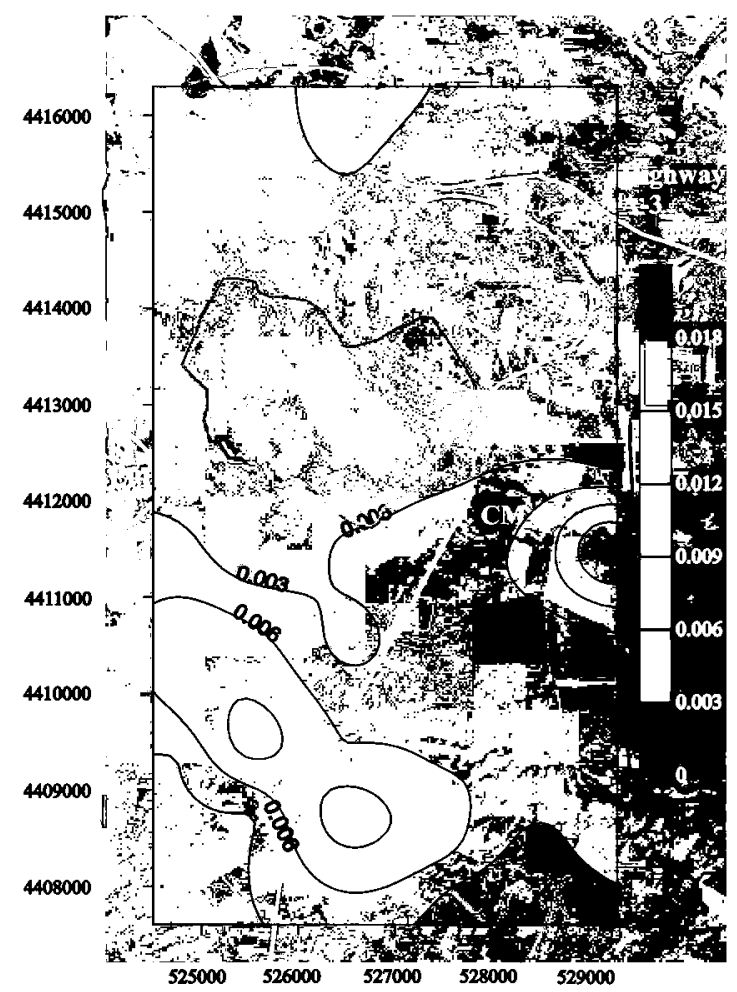

(b) $\Sigma$ HCHs

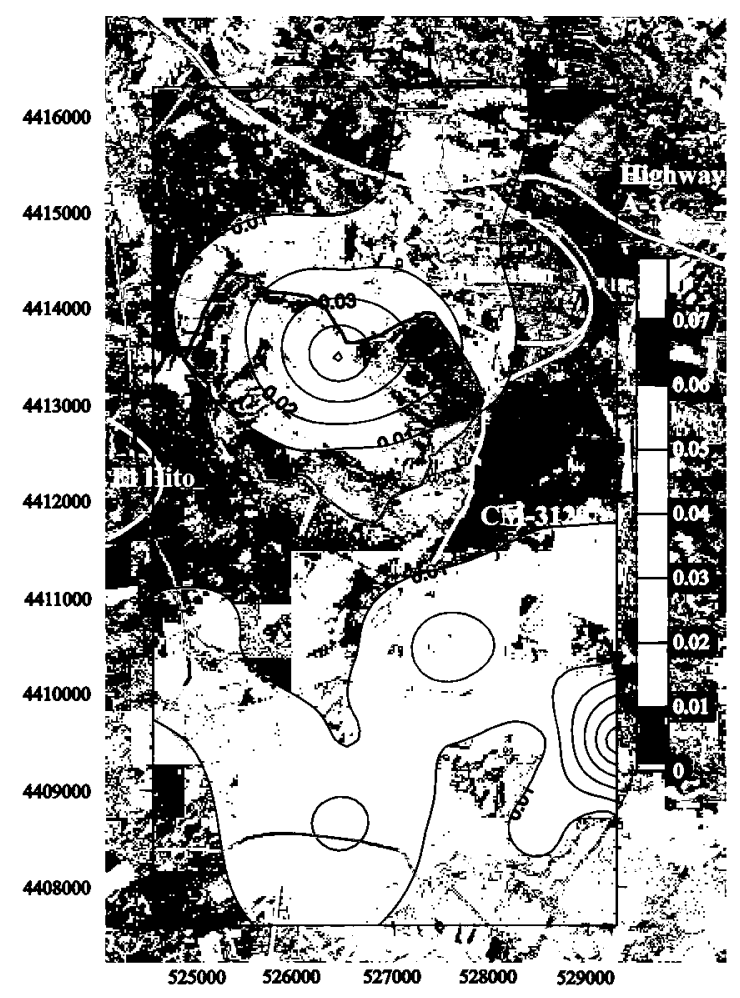

(d) $\Sigma$ Cyclodienes

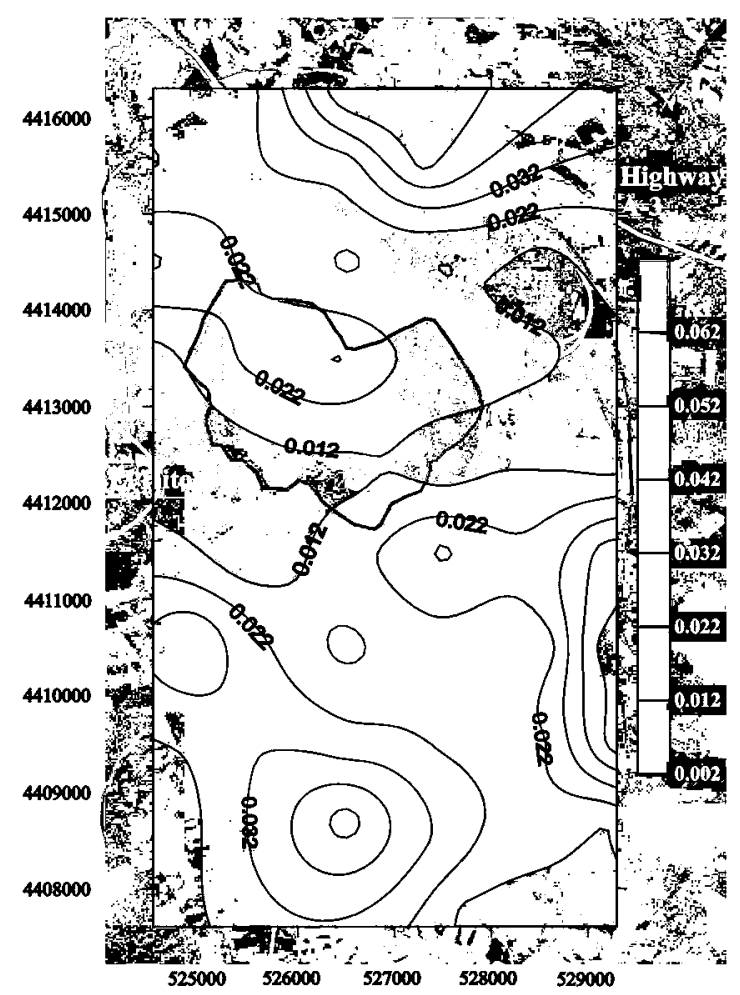

Fig. 3 Distribution maps for the catchment of a sum of concentrations of OCPs; $\mathbf{b}$ HCHs; $\mathbf{c}$ DDTs; $\mathbf{d}$ cyclodienes 


\subsection{1 $\mathrm{HCHs}$}

The total concentration of $\mathrm{HCHs}$, which accounted for $30.18 \%$ of OCPs, ranged from 0.24 to $70 \mu \mathrm{g} / \mathrm{kg}$. $\gamma-\mathrm{HCH}$ was the most abundant $\mathrm{HCH}(37 \%)$, followed by $\delta-\mathrm{HCH}(27.7 \%)$, $\alpha-\mathrm{HCH}(24.3 \%)$ and $\beta-\mathrm{HCH}(11 \%)$. Of the total pesticides, the most abundant was $\gamma-\mathrm{HCH}$, accounting for $11.2 \%$. The distribution of HCHs in the catchment showed two marked maxima (Fig. 3b), one in the lake area and the other next to the livestock farms in the southeast. Low values appeared in the centre of the catchment. HCB concentration values of ca. $0.1 \mu \mathrm{g} / \mathrm{kg}$ were found, accounting for $1.3 \%$ of total pesticides.

\subsubsection{DDTs}

The total concentration of DDTs ranged from $9.2 \times 10^{-2}$ to $16 \mu \mathrm{g} / \mathrm{kg}$ and accounted for $9.1 \%$ of total pesticides. $p, p^{\prime}-$ DDE and $p, p^{\prime}$-DDD were in similar proportion (45.8 and $48.9 \%$ ) of total DDTs. $p, p^{\prime}$-DDT was present in $44 \%$ of the samples and represented $9.1 \%$ of the DDTs. $o, p^{\prime}$-DDT was found in $94 \%$ of the samples, representing ca. $1 \%$ of the total concentration of OCPs. $o, p^{\prime}$-DDE and $o, p^{\prime}$-DDD were observed in only two samples. The highest concentration of DDTs appeared in the southern half of the catchment, marking several maxima, the highest being $0.017 \mathrm{mg} / \mathrm{kg}$ on the east border. The lowest values were in the northern half where the lake occurs (Fig. 3c).

\subsubsection{Cyclodienes}

The total concentration of cyclodienes ranged between 1 and $62 \mu \mathrm{g} / \mathrm{kg}$, accounting for $58 \%$ of total pesticides. Endrin was the most abundant, accounting for $16.6 \%$ of cyclodienes, followed by aldrin $(14 \%)$, endrinaldehyde $(10.7 \%)$, and heptachlor epoxide B (10.6\%). The remaining cyclodienes accounted for $<10 \%$.

As shown in the distribution map, the highest concentrations of cyclodienes were in the northern part of the catchment at $62 \mu \mathrm{g} / \mathrm{kg}$. Other maxima were found in the east and in the south of the catchment, next to livestock farms (Fig. 3d), with values around $58 \mu \mathrm{g} / \mathrm{kg}$.

\section{Discussion}

\subsection{Soil screening levels (SSLs)}

Soil screening levels can be defined as the concentration that does not reach the highest maximum acceptable risk to human health or ecosystems; however, if at least one concentration value exceeds the corresponding SSL, then a detailed risk assessment is required. Therefore, SSLs can be used to identify areas that need further investigation.

In this study, we consider the SSLs established in R.D. 09/2005 of the Spanish Legislation, but a comparison between these levels and those established by the Environmental Protection Agency of USA (USEPA) (Tables 1,2) is included. Of note, the USEPA SSLs are, in general, more restrictive than those established in the Spanish legislation for "industrial soil". In contrast, the Spanish legislation establishes lower SSLs for "urban soil" in most cases. Heptachlor is considered in the USEPA but not in R.D. 09/2005.

In order to determine the SSLs of exposure to the contaminants for human health, the Spanish legislation used the models developed by highly reputed technical, scientific or academic institutions, such as Joint Research Centre of the European Commission and the USEPA. The SSLs equations are the same as those used by the latter organisation but exposure data are particularized for Spain. To establish the SSLs for ecosystems, the Spanish Legislation used validated toxicological data from standardized tests conducted by the European Union and the Organization for Economic Cooperation and Development (OECD), together with the "estimated no-effect concentration (PNEC)" established by the EU.

In many cases, the concentrations of $\alpha-\mathrm{HCH}, \gamma-\mathrm{HCH}$ (lindane), aldrin, endrin, and heptachlor epoxide $\mathrm{B}$ in the lake sediments exceeded the SSLs for "human health in other uses of soil" (mainly agriculture and livestock) as established in the R.D. 09/2005 (Table 1). Moreover, in many cases $\gamma-\mathrm{HCH}$, aldrin, endrin and endosulfan (I and II) surpassed the SSL values for "ecosystems: soil organisms, aquatic organisms and terrestrial vertebrates", established in the same decree (Table 2). There was no concentration that exceeded the SSLs for human health in resident and industrial soil established by the USEPA. Of note, the SSLs for $\delta-\mathrm{HCH}$, heptachlor, endrin aldehyde, endrin ketone, endosulfan sulfate, and metoxichlor are not established in Spanish legislation. Among them, endrin aldehyde, $\delta-\mathrm{HCH}$ and heptachlor epoxide B showed remarkable total concentrations in the lake: 480,460 and $270 \mu \mathrm{g} / \mathrm{kg}$, respectively. For DDD and heptachlor epoxide B, SSLs are established only for "human health".

In some cases, the concentrations of $\gamma-\mathrm{HCH}$ (lindane), $\beta$-HCH, endrin, and heptachlor epoxide B in the catchment exceeded the SSL values for "human health in other uses of soil", as established in R.D. 09/2005 of the Spanish legislation (Table 1). Moreover, in some samples, $\gamma$-HCH, $\beta$-HCH, endrin, and endosulfan (I + II) surpassed the SSL values for "ecosystems: soil organisms, aquatic organisms and terrestrial vertebrates", established in the same decree. As in the lake, there was no concentration that exceeded the SSLs for resident and industrial soil 
Table 1 Soil screening levels (SSLs) for human health in different uses of soil according to R.D. 09/2005 of the Spanish legislation and resident and industrial soil of USEPA

\begin{tabular}{|c|c|c|c|c|c|}
\hline $\mathrm{OCP}$ & $\begin{array}{l}\text { Industrial use }{ }^{\mathrm{a}} \\
(\mathrm{mg} / \mathrm{kg})\end{array}$ & $\begin{array}{l}\text { Urban use }^{\mathrm{a}} \\
(\mathrm{mg} / \mathrm{kg})\end{array}$ & $\begin{array}{l}\text { Other uses }{ }^{\mathrm{a}} \\
(\mathrm{mg} / \mathrm{kg})\end{array}$ & $\begin{array}{l}\text { Resident soil }{ }^{\mathrm{b}} \\
(\mathrm{mg} / \mathrm{kg})\end{array}$ & $\begin{array}{l}\text { Industrial } \\
\text { soil }^{\mathrm{b}} \text { (mg/ } \\
\mathrm{kg} \text { ) }\end{array}$ \\
\hline$\alpha-\mathrm{HCH}$ & 1 & 0.1 & 0.01 & 0.08 & 0.36 \\
\hline Hexaclorobenzene & 1 & 0.1 & 0.01 & 0.21 & 0.96 \\
\hline$\beta-\mathrm{HCH}$ & 1 & 0.1 & 0.01 & 0.30 & 1.30 \\
\hline$\gamma-\mathrm{HCH}$ & 1 & 0.1 & 0.01 & 0.57 & 2.50 \\
\hline$\delta-\mathrm{HCH}$ & n.d. & n.d. & n.d. & n.d. & n.d. \\
\hline Heptachlor & n.d. & n.d. & n.d. & 0.13 & 0.63 \\
\hline Aldrin & 1 & 0.1 & 0.01 & 0.04 & 0.18 \\
\hline Heptachlor epoxide B & 1 & 0.1 & 0.01 & 0.07 & 0.33 \\
\hline Chlordane & 1 & 0.1 & 0.01 & 1.70 & 7.50 \\
\hline Endosulfan & 60 & 6 & 0.6 & 47 & 700 \\
\hline $4,4^{\prime}-\mathrm{DDE}$ & 60 & 6 & 0.6 & 2 & 9.30 \\
\hline Dieldrin & 1 & 0.1 & 0.01 & 0.03 & 0.14 \\
\hline Endrin & 1 & 0.1 & 0.01 & 1.90 & 25 \\
\hline $4,4^{\prime}$-DDD & 70 & 7 & 0.7 & 2.30 & 9.60 \\
\hline Endrin aldehyde & n.d. & n.d. & n.d. & n.d. & n.d. \\
\hline Endosulfan sulfate & n.d. & n.d. & n.d. & n.d. & n.d. \\
\hline 4,4'-DDT & 20 & 2 & 0.2 & 1.90 & 8.50 \\
\hline Endrin ketone & n.d. & n.d. & n.d. & n.d. & n.d. \\
\hline Metoxichlor & n.d. & n.d. & n.d. & 32 & 410 \\
\hline
\end{tabular}

Dirección General de Calidad y Evaluación Ambiental, Ministerio de Medio Ambiente (2007) n.d. not defined

${ }^{a}$ According to R.D. 09/2005 of the Spanish legislation

${ }^{\mathrm{b}}$ Resident and industrial soil of USEPA established by the USEPA. Among the compounds not included in these SSLs, those with the highest concentration (considered as the sum of the compound in the samples from the whole catchment) were endrin aldehyde $(110 \mu \mathrm{g} / \mathrm{kg})$, heptachlor epoxide B $(110 \mu \mathrm{g} / \mathrm{kg})$ and $\delta$-HCH $(150 \mu \mathrm{g} / \mathrm{kg})$.

\subsection{Origin of OCPs in the lake sediments}

Of note, HCHs and cyclodienes accounted for a high percentage of the total OCPs in the sediments (45.6 and $50.3 \%$, respectively), in contrast to DDTs, which accounted for only $3 \%$. These observations can be attributed to the banning of DDT in Spain in 1976 (BOE 1976), in contrast to $\mathrm{HCHs}, \mathrm{HCB}$ and the cyclodienes aldrin, endrin, dieldrin, chlordane and heptachlor, which were banned in 1994 (BOE 1994). The rest of cyclodienes were regulated and forbidden in the Rotterdam Convention (2004), except for endosulfan, which was banned in 2008 and in 2014 its use was allowed under very stricted circumstances (BOE 2013). Likewise, the high hydrophobic character of DDTs should be taken into consideration (ATSDR 2002a).

\subsection{1 $\mathrm{HCHs}$}

HCHs might be considered as water-soluble compounds compared to the rest of OCPs ( $\log \mathrm{K}_{\mathrm{ow}}$ between 3 and 4; Table 3) (Agency for Toxic Substances and Disease Registry, ATSDR 2005). They are highly adsorbed in soil $\left(\mathrm{K}_{\mathrm{oc}}=2.8 \times 10^{3}\right.$; Table 3$)$ but can be released into water by suspended particles, rainfall and surface water runoff; they can also reach groundwater. Both in water and soil, they are broken down into less toxic substances by algae, fungi and bacteria, but the process may take a long time (ATSDR 2005).

Lindane comprises 99\% $\gamma-\mathrm{HCH}$, whereas technical $\mathrm{HCH}$ is made up of $55-80 \% \alpha-\mathrm{HCH}, 5-14 \% \beta-\mathrm{HCH}, 8-15 \%$ $\gamma-\mathrm{HCH}$ and $2-16 \% \delta$-HCH (Metcalf 1955). The $\alpha-\mathrm{HCH} / \gamma-$ $\mathrm{HCH}$ ratio is commonly used to determine the source of HCHs, i.e. a value between 4.64 and 5.83 suggests application of technical $\mathrm{HCH}$ while a value approaching zero points to a possible recent input of lindane (Zhang et al. 2004). The values for the lake ranged from 0 to 10 , with an average of 3.47 (Fig. 4a), indicating a mixed contribution, with both a recent input of lindane and historical application of technical $\mathbf{H C H}$ in areas with the highest values (> 5.83; Jiang et al. 2009). 
Table 2 Soil screening level (SSL) for ecosystems in different organisms according to R.D. 09/2005 of the Spanish legislation

\begin{tabular}{|c|c|c|c|}
\hline OCP & $\begin{array}{l}\text { Soil organ- } \\
\text { isms (mg/ } \\
\mathrm{kg})\end{array}$ & $\begin{array}{l}\text { Aquatic } \\
\text { organisms } \\
(\mathrm{mg} / \mathrm{kg})\end{array}$ & $\begin{array}{l}\text { Terrestrial } \\
\text { vertebrates } \\
(\mathrm{mg} / \mathrm{kg})\end{array}$ \\
\hline$\alpha-\mathrm{HCH}$ & n.d. & 0.25 & 0.05 \\
\hline Hexachlorobencene & 5.7 & 0.01 & 0.01 \\
\hline$\beta-\mathrm{HCH}$ & n.d. & 0.38 & 0.01 \\
\hline$\gamma-\mathrm{HCH}$ & 0.01 & 0.01 & 0.23 \\
\hline - $-\mathrm{HCH}$ & n.d. & n.d. & n.d. \\
\hline Heptachlor & n.d. & n.d. & n.d. \\
\hline Aldrin & 0.01 & 0.01 & 0.01 \\
\hline Heptachlor epoxideB & n.d. & n.d. & n.d. \\
\hline Chlordane & 0.04 & 0.01 & 0.01 \\
\hline Endosulfan & 0.01 & 0.01 & 0.04 \\
\hline $4,4^{\prime}-\mathrm{DDE}$ & 0.14 & 0.01 & 0.01 \\
\hline Dieldrin & 0.13 & 0.01 & 0.01 \\
\hline Endrin & n.d. & 0.01 & 0.01 \\
\hline $4,4^{\prime}-\mathrm{DDD}$ & n.d. & n.d. & n.d. \\
\hline Endrin aldehyde & n.d. & n.d. & n.d. \\
\hline Endosulfan sulfate & n.d. & n.d. & n.d. \\
\hline $4,4^{\prime}-\mathrm{DDT}$ & n.d. & 0.01 & 0.01 \\
\hline Endrin ketone & n.d. & n.d. & n.d. \\
\hline Metoxichlor & n.d. & n.d. & n.d. \\
\hline
\end{tabular}

Dirección General de Calidad y Evaluación Ambiental, Ministerio de Medio Ambiente (2007)

n.d. not defined
These pesticides show high biodegradability in comparison with DDTs. $\boldsymbol{\gamma}$-HCH can undergo a petrochemical transformation to become its isomer $\alpha-\mathrm{HCH}$, but can also be transformed to $\beta-\mathrm{HCH}$ in the environment (El-Naggar, et al. 2013). $\alpha-\mathrm{HCH}$ can be transformed to $\beta-\mathrm{HCH}$ and $\delta-\mathrm{HCH}$ by the action of soil microbes (Wu et al. 1997; El Nemr et al. 2012). In our view, the latter process would best explain the high amount of $\delta-\mathbf{H C H}$ in the El Hito Lake sediments, where it accounted for $23.2 \%$ of all $\mathrm{HCHs}$, as there is a small content of $\delta-\mathrm{HCH}(2-16 \%)$ in technical $\mathbf{H C H}$ and $\alpha-\mathrm{HCH}$ accounts for 55-80\% (Metcalf 1955).

$\beta$-HCH is more lipophilic, stable and persistent because it is easily adsorbed by soil organic matter, shows low solubility in water and evaporates with more difficulty $\left(\mathrm{P}_{\mathrm{v}}=3.52 \times 10^{-5}\right.$; Table 3$)$. These characteristics make it a better indicator of degradation (Mackay et al. 1997; Doong et al. 2002). $\beta-\mathrm{HCH}$ and $\gamma-\mathrm{HCH}$ are the most persistent HCHs and can remain in the environment for years. They are degraded by microorganisms and hydrolysis under alkaline conditions and this degradation can be favoured in anaerobic environments (ATSDR 2005). The $\beta-\mathrm{HCH} /(\alpha+\gamma)-\mathrm{HCH}$ ratio is used for better determination of the origin of HCHs. According to Liu et al. $(2008,2012)$, values $<0.5$ indicate either a recent application of lindane or an atmospheric source, whereas those $\geq 0.5$ indicate that $\mathbf{H C H}$ derives from the historical use of technical $\mathrm{HCH}$ or lindane. In the lake sediments, the mean value of $\beta-\mathrm{HCH} /(\alpha+\gamma)$-HCH was 0.23 , indicating a certain degree, although not significant, of $\mathrm{HCH}$ degradation and thus a possible recent input of lindane.
Table 3 Main physicochemical properties of OCPs (ATSDR 1996, 2002a, b, 2005; RAIS 2015)

\begin{tabular}{llll}
\hline OCP & $\begin{array}{l}\text { Organic carbon partition } \\
\text { coefficient }(\mathrm{L} / \mathrm{kg})\end{array}$ & $\begin{array}{l}\text { Log of octanol-water partition } \\
\text { coefficient }\left(\mathrm{Log} \mathrm{K}_{\mathrm{ow}}\right)\end{array}$ & $\begin{array}{l}\text { Vapor } \\
\text { pressure } \\
(\mathrm{mmHg})\end{array}$ \\
\hline$\gamma$-HCH & $2.81 \mathrm{E}+03$ & $3.72 \mathrm{E}+00$ & $3.52 \mathrm{E}-05$ \\
$\alpha-\mathrm{HCH}$ & $2.81 \mathrm{E}+03$ & $3.80 \mathrm{E}+00$ & $3.52 \mathrm{E}-05$ \\
$\beta-\mathrm{HCH}$ & $2.81 \mathrm{E}+03$ & $3.78 \mathrm{E}+00$ & $3.52 \mathrm{E}-05$ \\
$\delta$-HCH & $2.81 \mathrm{E}+03$ & $4.14 \mathrm{E}+00$ & $3.52 \mathrm{E}-05$ \\
$\mathrm{HCB}$ & $6.20 \mathrm{E}+03$ & $5.73 \mathrm{E}+00$ & $1.80 \mathrm{E}-05$ \\
DDD. $p \cdot p^{\prime}$ & $1.18 \mathrm{E}+05$ & $6.02 \mathrm{E}+00$ & $1.35 \mathrm{E}-06$ \\
DDE. $p \cdot p^{\prime}$ & $1.18 \mathrm{E}+05$ & $6.51 \mathrm{E}+00$ & $6.00 \mathrm{E}-06$ \\
DDT. $p \cdot p^{\prime}$ & $1.69 \mathrm{E}+05$ & $6.91 \mathrm{E}+00$ & $1.60 \mathrm{E}-07$ \\
Chlordane & $6.75 \mathrm{E}+04$ & $6.16 \mathrm{E}+00$ & $9.98 \mathrm{E}-06$ \\
Endosulfan & $6.76 \mathrm{E}+03$ & $3.83 \mathrm{E}+00$ & $6.00 \mathrm{E}-07$ \\
Aldrin & $8.20 \mathrm{E}+04$ & $6.50 \mathrm{E}+00$ & $1.20 \mathrm{E}-04$ \\
Dieldrin & $2.01 \mathrm{E}+04$ & $5.40 \mathrm{E}+00$ & $3.00 \mathrm{E}-06$ \\
Endrin & $2.01 \mathrm{E}+04$ & $5.20 \mathrm{E}+00$ & $3.00 \mathrm{E}-06$ \\
Endrin aldehyde & $3.27 \mathrm{E}+03$ & $4.80 \mathrm{E}+00$ & $2.00 \mathrm{E}-07$ \\
Endrin ketone & $9.72 \mathrm{E}+03$ & $4.99 \mathrm{E}+00$ & $5.51 \mathrm{E}-06$ \\
Heptachlor & $4.13 \mathrm{E}+04$ & $6.10 \mathrm{E}+00$ & $4.00 \mathrm{E}-04$ \\
Heptachlor epoxide & $1.01 \mathrm{E}+04$ & $4.98 \mathrm{E}+00$ & $1.95 \mathrm{E}-05$ \\
Methoxychlor & $2.69 \mathrm{E}+04$ & $5.08 \mathrm{E}+00$ & $4.17 \mathrm{E}-05$ \\
\hline & & &
\end{tabular}


(a) HCHs degradation

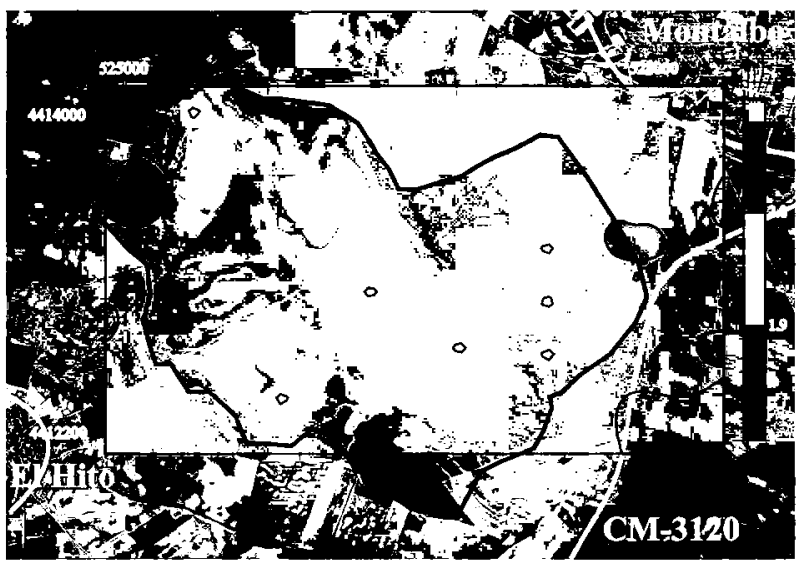

(c) $0, p^{\prime}-D D T / p, p '-D D T$

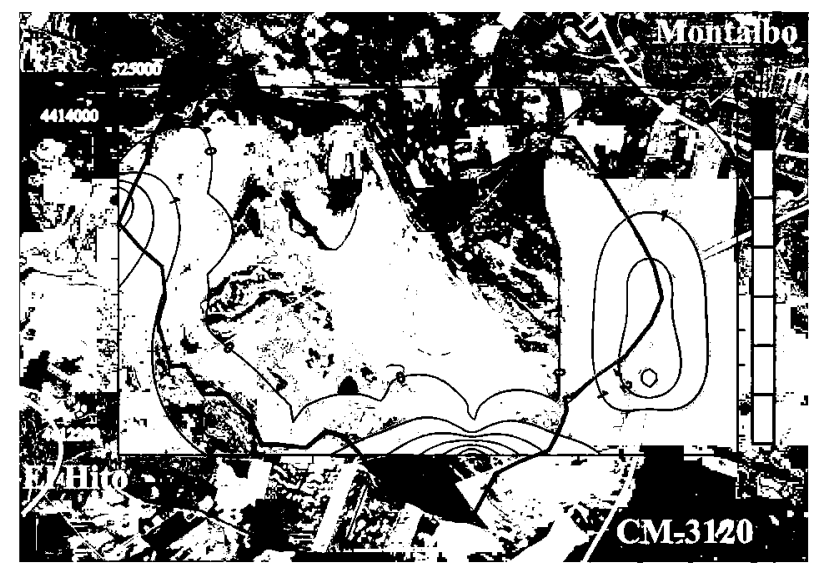

(e) $\alpha-/ \gamma$-endosulfan

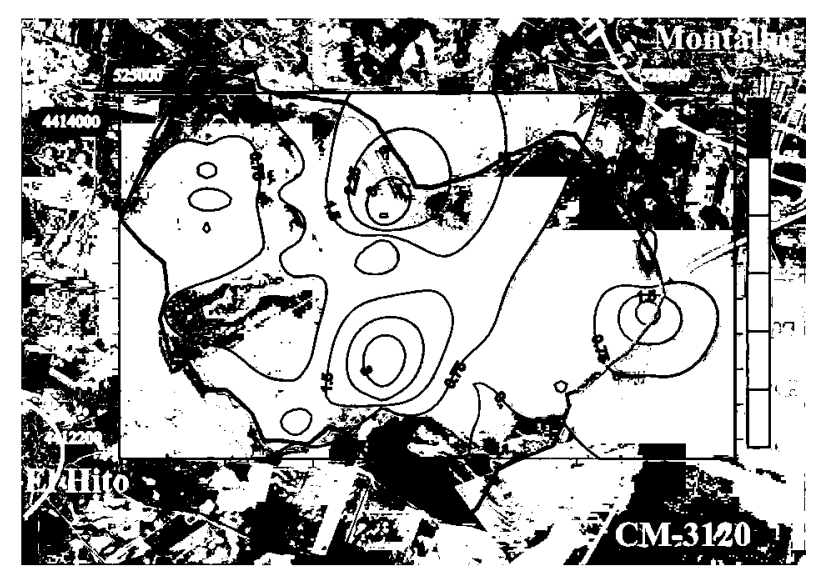

(b) $(\mathrm{DDE}+\mathrm{DDD}) / \mathrm{\Sigma DDT}$

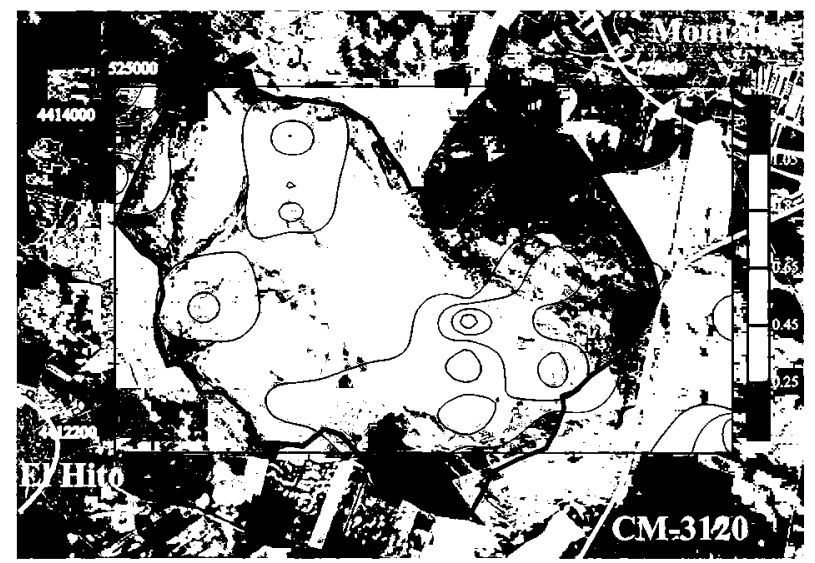

(d) $\gamma$-/o-chlordane

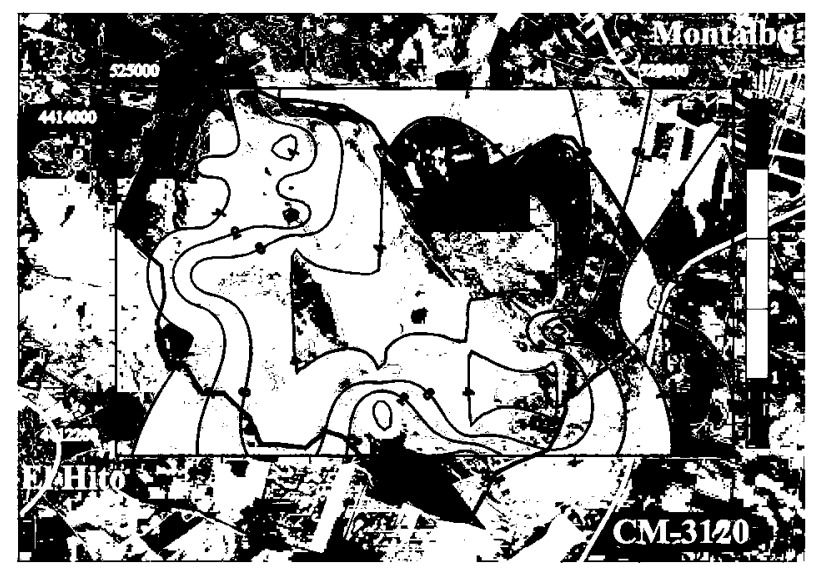

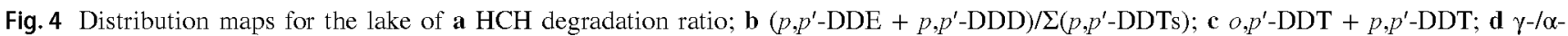
chlordane; e $\alpha$ - $/ \beta$-endosulfan

By combining these two ratios: $\frac{\alpha-\mathrm{HCH}}{\gamma-\mathrm{HCH}}$ and $\frac{\beta-\mathrm{HCH}}{(\alpha+\gamma)-\mathrm{HCH}}$ we constructed a new index to infer the degradation of HCHs with three main intervals:
1. No degradation: $\gamma$-HCH present, with $\alpha$ - and $\beta-\mathrm{HCH}$ absent

2. Low/moderate degradation: presence of $\alpha-\mathrm{HCH}$ and/or $\left.\frac{\beta-\mathrm{HCH}}{(\alpha+\gamma)-\mathrm{HCH}}<0.5\right)$ 
3. High degree of degradation $\frac{\beta-\mathrm{HCH}}{(\alpha+\gamma)-\mathrm{HCH}}>0.5$, or only $\beta$-HCH present.

In the distribution map of the $\mathrm{HCH}$ degradation index (Fig. 4a), several maxima were observed, mainly in the central-east area of the lake and in the zone nearest to El Hito village, thereby pointing to a high degree of degradation. Most of the lake sediments showed low to moderate degradation.

The concentration of HCBs was low in the lake sediments (ca. $0.1 \mu \mathrm{g} / \mathrm{kg}$ ). These compounds may have originated as impurities and/or byproducts of solid waste combustion (cf. Jiang et al. 2009), as there is garbage dump in the vicinity of the lake, close to Montalbo village. We discarded the notion that chlorination processes and/or chemical industrial processes (Jiang et al. 2009) produced the HCBs in the lake sediments.

\subsubsection{DDTs}

DDTs are highly stable and persistent, are widely distributed and can remain (50\%) in soil for 10 or $15 \mathrm{yr}$ after application. In contrast to HCHs, DDTs are hydrophobic and therefore show low water solubility (log $\mathrm{K}_{\mathrm{ow}} 6-7$; Table 3 ). They are also less susceptible to volatilization $\left(\mathrm{P}_{\mathrm{v}}\right.$ between $10^{-6}$ and $10^{-7} \mathrm{mmHg} / 25^{\circ} \mathrm{C}$; Table 3 ) and more easily adsorbed in soil (Koc ca. 105; Table 3), so they could become attached to soil particles and be transported to the lake (ATSDR 2002a; Gao et al. 2013), although runoff is scarce.

The application of dicofol and technical DDT in agriculture is an important source of DDTs in the environment. Technical DDT contains around $77.1 \%$ of $p, p^{\prime}$-DDT, $14.9 \%$ of $o, p^{\prime}$-DDT and $4 \%$ of $p, p^{\prime}$-DDE and impurities, while dicofol contains 3-7\% DDTs as impurities (Zhu et al. 2005). The $\left(p, p^{\prime}\right.$-DDE $+p, p^{\prime}$-DDD $) / \Sigma\left(p, p^{\prime}\right.$-DDTs $)$ ratio exceeded the cutoff value of 0.5 in almost all samples, indicating long term weathering and therefore that DDTs originated primarily from historical sources, since $p, p^{\prime}$-DDT is metabolized to both $p, p^{\prime}$-DDE and $p, p^{\prime}$-DDD (Hitch and Day 1992).

Aerobic biodegradation of DDT generates its metabolite, DDE. In this case (shallow lake), DDE would be expected to be more abundant than DDD (Huang et al. 2006). However, the seasonal decomposition of aquatic plants generates a layer of sapropelic appearance: anaerobic and anoxic conditions that favour the genesis of DDD. Of note, the individual concentrations of these compounds were around $0.1 \mu \mathrm{g} / \mathrm{kg}$, and interpretation of the values should be made with care.

Two remarkable maxima in the $\left(p, p^{\prime}\right.$-DDE $+p, p^{\prime}$-DDD $) /$ $\Sigma\left(p, p^{\prime}\right.$-DDTs $)$ ratio were in the southeastern area near the CM-3120 road and in the northwest (Fig. 4b), that is to say, where DDT was more degraded.
The $o, p^{\prime}$-DDTs were detected in only six samples and $o-p^{\prime}$ DDT in four of them. The few samples in which we were able to calculate the $o, p^{\prime}-/ p, p^{\prime}$-DDT ratio showed values between 1.3 and 9.3. These values indicate that dicofol, a compound that includes a high content of $o, p^{\prime}$-DDT as impurities (Qiu et al. 2005), may be the main source. Dicofol is a moderately hazardous, persistent and bioaccumulative compound, classified as a possible carcinogen by the U.S. Environmental Protection Agency (Holder 1986).

The distribution map of $o, p^{\prime}-1 p, p^{\prime}$-DDT (Fig. $4 \mathrm{c}$ ) indicated that the dicofol origin was related to the crop fields surrounding the lake.

\subsubsection{Cyclodienes}

Chlordane is a complex mixture of 26 compounds (Solomon and Weiss 2002), of which $15 \%$ is cis-chlordane $(\gamma$-chlordane) and 15\% trans-chlordane ( $\alpha$-chlordane). Moreover, one of the degradation by products of chlordane is trans-chlordane, so the ratio $\gamma$ - $/ \alpha$-chlordane ratio helps determine its origin. Application of chlordane, both recent $(\gamma-/ \alpha$-chlordane $>1)$ and historical $(\gamma-/ \alpha$-chlordane $<1)$, was proposed, since the ratio showed values ranging from 0 to 4 (cf. Bidleman et al. 2002). Minima were observed in the eastern and western areas of the lake (Fig. 4d), indicating a historical origin, while values increased towards the central part, where we inferred a more recent input.

In $68.8 \%$ of the samples, we observed trans-chlordane and in $37.7 \%$ cis-chlordane, the sum of them accounting for approximately only $0.43 \%$ of cyclodienes. Therefore, the values should be interpreted with care. These proportions can be explained because chlordane has an approximate half-life of 1 year (Stockhom Convention 2001), although its degradation rate can be slow since it can be attached strongly to soil particles and remain for up to 20 year in the environment (Rathore and Nollet 2012).

Technical endosulfan consists mainly (94\%) of two isomers: $70 \%$ of $\alpha$-endosulfan (I) and $30 \%$ of $\beta$-endosulfan (II) (Shetty et al. 2000; Pathak et al. 2008). The former is more readily degraded in soil than the latter, which is metabolized to $\alpha$-endosulfan over time (World Health Organization 1984). Endosulfan sulfate is the oxidation product of technical endosulfan and is equally toxic but more persistent (Shetty et al. 2000; Pathak et al. 2008).

The $\alpha$-/ $\beta$-endosulfan ratio in technical endosulfan is 2.33 , so a lower value indicates degradation (Jiang et al. 2009). In $57.1 \%$ of the samples, we detected $\alpha$-endosulfan and in $50.4 \% \beta$-endosulfan. Most values of the ratio were $<2.33$, thereby pointing to historical application with a relative recent input, as reflected in greater degradation of $\alpha$-endosulfan than $\beta$-endosulfan. Furthermore, $\beta$-endosulfan is metabolized to $\alpha$-endosulfan with time; however, if only $\alpha$-endosulfan is present, it is not 
possible to determine its origin. On the basis of the concentration of these compounds in the lake area $(260 \mu \mathrm{g} /$ $\mathrm{kg} \alpha$-endosulfan, $210 \mu \mathrm{g} / \mathrm{kg} \beta$-endosulfan, and $70 \mu \mathrm{g} / \mathrm{kg}$ endosulfan sulfate), we confirmed an historical origin since both isomers had a similar concentration and endosulfan sulfate was present (cf. Shetty et al. 2000; Pathak et al. 2008), although in relatively low concentration.

In the distribution map of the $\alpha$-/ $\beta$-endosulfan ratio (Fig. 4e), three main maxima were observed in the centre of the lake and in its eastern part, indicating a relatively recent input of technical endosulfan. In the rest of the lake, values indicated degradation of these pesticides.

Although there is no ratio for determining the source of the remaining cyclodienes, they could be estimated from the concentrations of the main pesticides (aldrin, endrin and heptachlor) and their metabolites (dieldrin, endrin aldehyde, endrin ketone and heptachlor epoxide B).

It is known that $56 \%$ of aldrin is converted to dieldrin by epoxidation under aerobic conditions in biologically active soils (El-Naggar et al. 2013). Although the half-life of aldrin is 1.5-5.2 years, both aldrin and dieldrin are extremely persistent, depending on the type of sediment (El-Naggar et al. 2013). Dieldrin can rearrange to endrin and takes years to degrade since it does not evaporate easily and attaches strongly to soil particles $\left(\mathrm{Koc}=2.01 \times 10^{4}\right.$ and $\mathrm{P}_{\mathrm{v}}=3.0 \times 10^{-6}$; Table 3$)($ GES AMP 1993, Rathore and Nollet 2012). Both compounds have low water solubility, further hindering their degradation. However, a predominant recent application was deduced through the total concentration of aldrin $(350 \mu \mathrm{g} /$ $\mathrm{kg})$ in contrast to that of dieldrin $(40 \mu \mathrm{g} / \mathrm{kg})$.

Endrin is degraded to endrin aldehyde and endrin ketone and can remain in soil for up to 12 years (Stockholm Convention 2001). A predominant historical application of endrin was deduced for the lake sediments on the basis of the concentration of the metabolites: $480 \mu \mathrm{g} /$ $\mathrm{kg}$ for endrin aldehyde and $110 \mu \mathrm{g} / \mathrm{kg}$ for endrin ketone vs. endrin, which was $270 \mu \mathrm{g} / \mathrm{kg}$. However, a relatively recent input cannot be ruled out.

Heptachlor becomes degraded to heptachlor epoxide $\mathrm{B}$ by biological and photochemical processes (Rathore and Nollet 2012). The latter is extremely persistent in soil and can remain for 14-16 years after application (Rathore and Nollet 2012). On the basis of the concentrations of these two pesticides in the lake sediments $(270 \mu \mathrm{g} / \mathrm{kg}$ for heptachlor epoxide B and $90 \mu \mathrm{g} / \mathrm{kg}$ for heptachlor), we propose that they represent a mainly historical input. It is believed that the toxicity of heptachlor affects principally birds, decreasing their population (Stockholm Convention 2001). However, the SSLs for heptachlor for ecosystems and for human health are not defined in the Spanish legislation.

\subsection{Origin of OCPs in the catchment}

\subsubsection{HCHs}

The $\alpha-\mathrm{HCH} / \gamma-\mathrm{HCH}$ values in the catchment sediments varied between 0 and 10 , with a mean of 4.58 , indicating (coinciding with the interpretation based on the values from the lake sediments) both a historical contribution of technical $\mathrm{HCH}$ and a recent input of lindane. In our view, the high concentration of $\delta-\mathrm{HCH}$ is the result of $\alpha-\mathrm{HCH}$ degradation, as occurred in the lake (cf. Wu et al. 1997; El Nemr et al. 2012).

The values of the $\beta-\mathrm{HCH} /(\alpha+\gamma)-\mathrm{HCH}$ ratio, with an average of 0.46 and a range from 0 to 2.8 , indicate mainly moderate degradation (cf. Liu et al. 2008, 2012). The index that infers degradation of HCHs, constructed from these two ratios (Fig. 5a), showed moderate degradation (mean value 2.23), with some maxima in the middle and southern part of the catchment. The lowest values were in the northern half of the catchment, mainly in the zone of the lake, indicating less degradation.

The $\alpha-\mathrm{HCH}$ distribution map (Fig. 6a) shows that the highest concentration values of this compound were in the lake area. This observation is attributed to the fact that this OCP is more water soluble. The same distribution pattern was found for $\delta-\mathrm{HCH}$. In contrast, the highest concentration values of $\mathrm{HCB}$ in the catchment were in the southern half (Fig. 6b) since this OCP is hydrophobic and thus was not detected in the lake area. Similar distributions also occurred for the hydrophobic $\beta-\mathrm{HCH}$ and $\gamma-\mathrm{HCH}$.

\subsubsection{DDTs}

The values for the $\left(p, p^{\prime}\right.$-DDE $+p, p^{\prime}$-DDD $) / \Sigma\left(p, p^{\prime}\right.$-DDTs $)$ ratio exceeded 0.5 in all cases, thereby indicating that DDTs originated primarily from historical sources, since $p, p^{\prime}$-DDT is metabolized to $p, p^{\prime}$-DDE and $p, p^{\prime}$-DDD (Hitch and Day 1992). Some remarkable minima were observed in the surroundings of the lake and in the central part of the catchment (Fig. 5b), where DDTs were less degraded than in the rest of the area.

Both $o, p^{\prime}$-DDT and $p, p^{\prime}$-DDT were simultaneously detected in 20 samples, $o, p^{\prime}-/ p, p^{\prime}$-DDT ratio of between 0.5 and 15 being attained. We interpreted this to be that most samples with values $>1.3$ had a dicofol source (cf. Qiu et al. 2005). In contrast, technical DDT was likely to be the major source in samples with values $<1.3$. The distribution map for the $o, p^{\prime}-/ p, p^{\prime}$-DDT ratio (Fig. 5c) revealed a maximum in the east, near El Hito village, although almost the whole eastern and central area showed values $>1.3$. 
(a) HCHs degradation

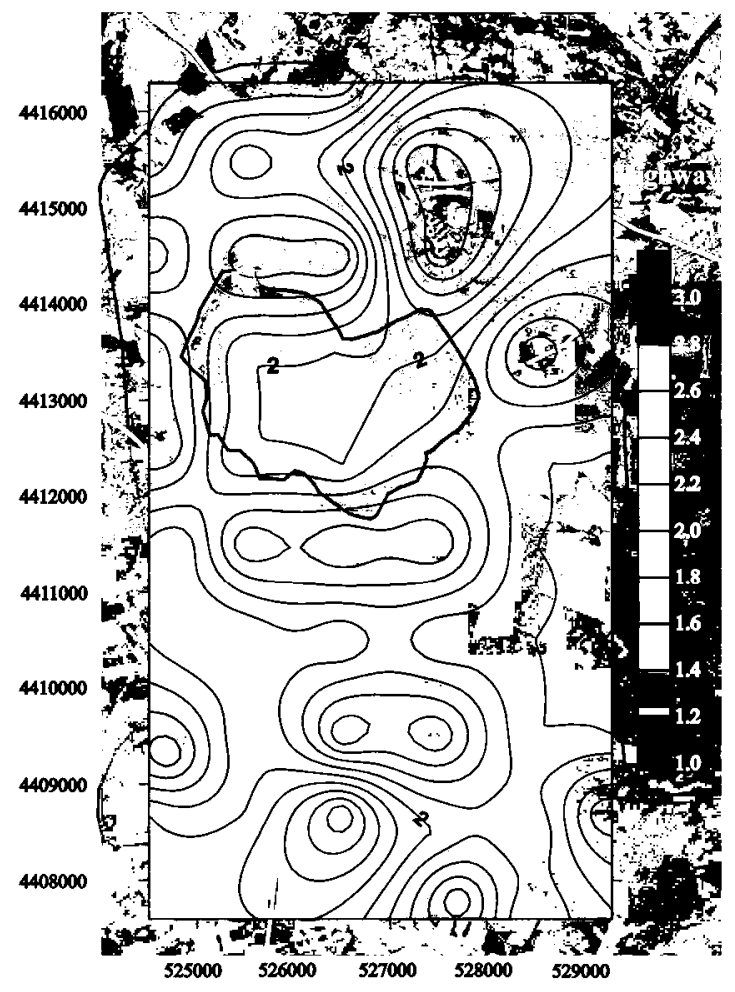

(c) $\mathbf{o , p}-\mathrm{DDT} / \mathrm{p}, \mathbf{p}$ '-DDT

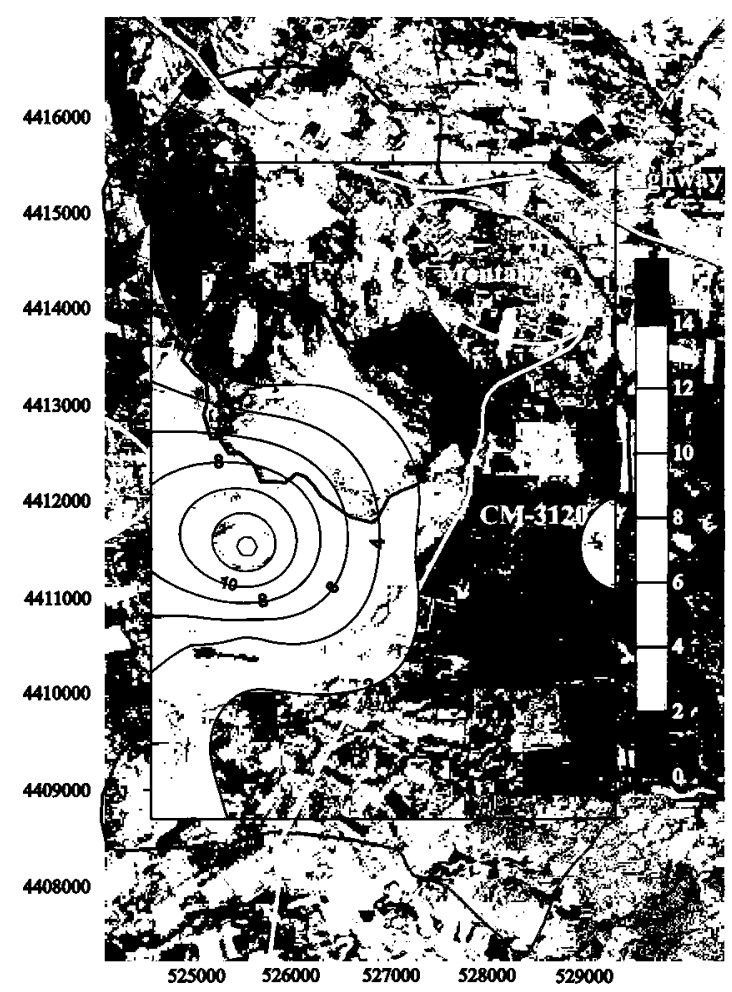

(b) $(\mathrm{DDE}+\mathrm{DDD}) / \Sigma \mathrm{DDT}$

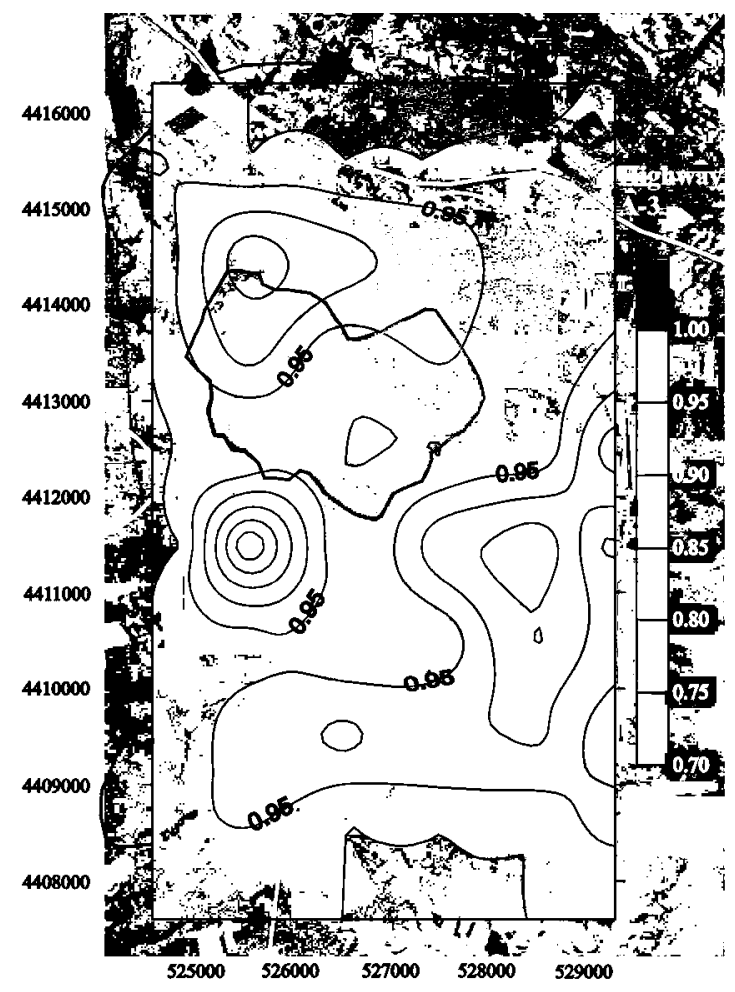

(d) $\gamma$-/a-chlordane

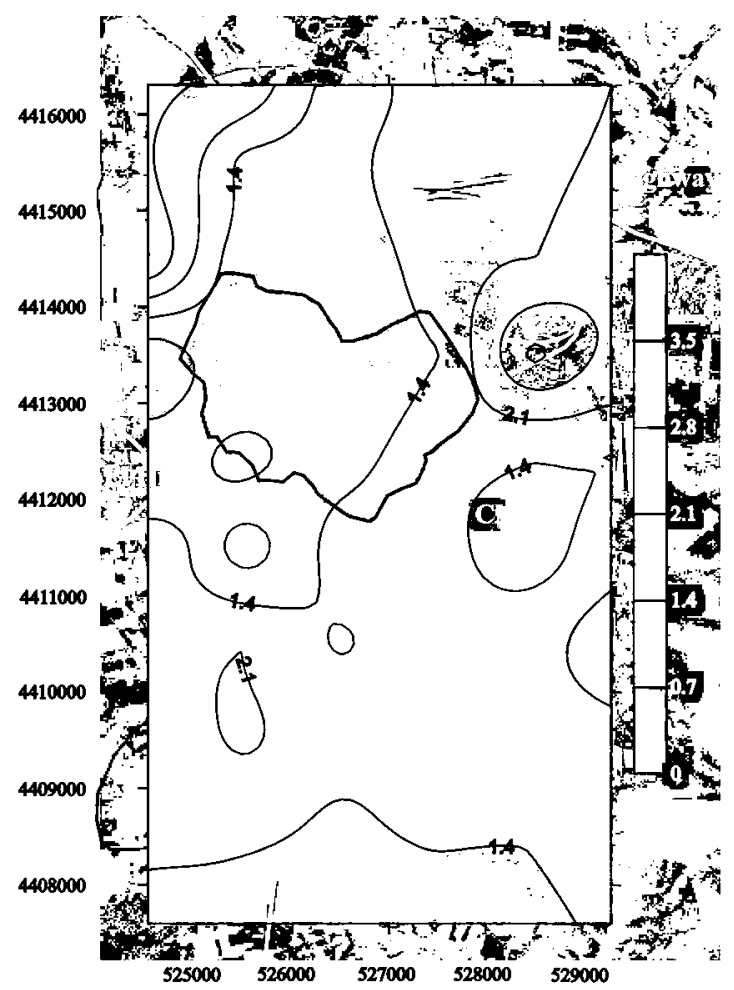

Fig. 5 Distribution maps for the catchment of a HCH degradation ratio; $\mathbf{b}\left(p, p^{\prime}-\mathrm{DDE}+p, p^{\prime}-\mathrm{DDD}\right) / \Sigma\left(p, p^{\prime}-\mathrm{DDTs}\right) ; \mathbf{c} o, p^{\prime}-\mathrm{DDT}+p, p^{\prime}-\mathrm{DDT} ; \mathbf{d}$ $\gamma$-/ $\alpha$-chlordane 
(a) $a-\mathrm{HCH}$

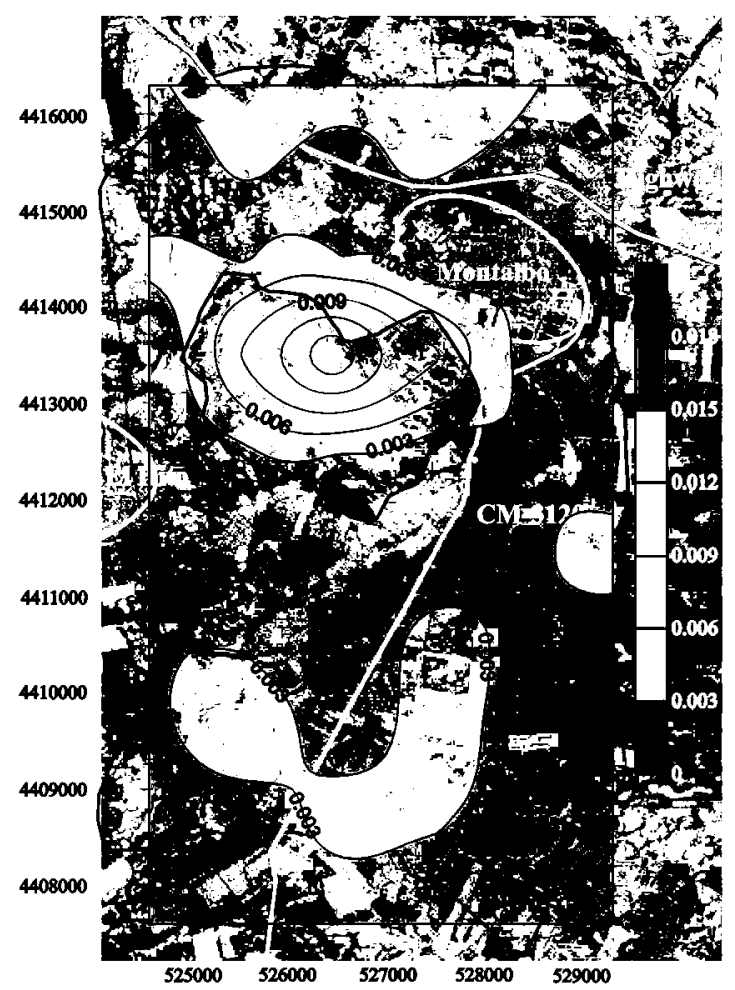

(b) $\mathrm{HCB}$

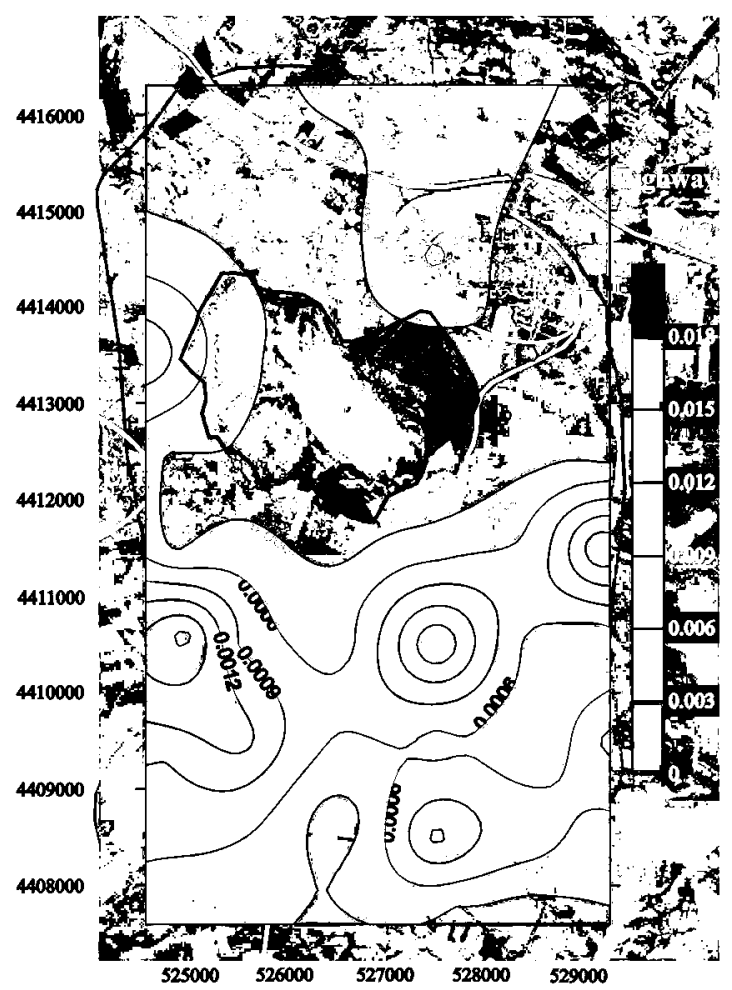

Fig. 6 Distribution maps for the catchment of $\mathbf{a} \alpha-\mathrm{HCH}$; b BHC

\subsubsection{Cyclodienes}

With an average value of 1.62 in the catchment (Fig. 5d), the $\gamma-/ \alpha$-chlordane ratio indicated a recent application $(>1)$ of chlordane plus some historical input $(<1)$. Of note, both trans-chlordane and cis-chlordane were detected together in almost $100 \%$ of the samples, and they accounted for ca. $4.8 \%$ of cyclodienes (in contrast to the lake, where the proportion was $0.43 \%$ ). This observation can be explained by the fact that chlordane is immobile or slightly mobile in soil and insoluble in water (EPA web) and will therefore remain near the area where it was originally applied.

Some maxima were observed in the north of the catchment (Fig. 5d), indicating the most recent input in this area; in contrast, two marked minima in the western and eastern parts suggested a historical contribution.

Detection in the samples overall was $56 \%$ for $\alpha$-endosulfan and $32 \%$ for $\beta$-endosulfan. In the 16 samples in which $\beta$-endosulfan appeared, the $\alpha-/ \beta$-endosulfan ratio indicated mainly historical application, as the values were $<2.33$ (Jiang et al. 2009). Given the total concentration of $100 \mu \mathrm{g} / \mathrm{kg}$ for $\alpha$-endosulfan, $60 \mu \mathrm{g} / \mathrm{kg}$ for $\beta$-endosulfan and $60 \mu \mathrm{g} / \mathrm{kg}$ for endosulfan sulfate, a historical origin could be inferred for endosulfan.

To determine the origin of the remaining of cyclodienes, we estimated their concentration values by measuring those of the main cyclodienes (aldrin, endrin and heptachlor) and their metabolites (dieldrin, endrin aldehyde, endrin ketone and heptachlor epoxide B).

A predominant relatively recent application was deduced for aldrin, since its total concentration in the catchment was $150 \mu \mathrm{g} / \mathrm{kg}$, in contrast to the total concentration of its metabolite dieldrin, which was much lower $(50 \mu \mathrm{g} / \mathrm{kg})$.

Both historical and relatively recent application was inferred for endrin, as the total concentration in the catchment was $180 \mu \mathrm{g} / \mathrm{kg}$, while its breakdown products endrin aldehyde and endrin ketone were present at a concentration of 110 and $60 \mu \mathrm{g} / \mathrm{kg}$, respectively.

The heptachlor detected in the catchment was due mainly to historical application, as reflected in the total concentration of this compound $(20 \mu \mathrm{g} / \mathrm{kg})$ in contrast to that of heptachlor epoxide B $(110 \mu \mathrm{g} / \mathrm{kg})$.

\subsection{Atmospheric origin of OCPs}

OCPs are susceptible to air transport. Liu et al. (2010) observed seasonal variations in the concentration of $\mathrm{HCB}$, HCHs and DDT compounds in the air of Western Sichuan (China). These variations were due either to higher pesticide 
usage in summer or to higher temperatures, which led to greater evaporation in source regions. Daly et al. (2007) measured OCPs in the air of Costa Rica and was able to identify important contaminants at the regional level and areas of elevated concentrations. Moreover, Wania et al. (1997) and Wania (2006) reported OCPs in the Artic derived from air transport.

The $\Sigma H C H / \Sigma D D T$ ratio indicated that a large number of samples ( $85 \%$ from the lake and $83 \%$ from the catchment) showed a predominance of HCHs over DDTs (values $>1$ ), in spite of the tendency of the former to be metabolized to other compounds, such as pentachlorocyclohexane or tetrachlorobenzene, and their greater water solubility than DDTs (it is therefore likely that HCHs decrease faster than DDTs with time; El-Naggar et al. 2013).

Therefore, in our opinion, and taking into account that most $\mathrm{HCHs}$ are released to the atmosphere and have greater volatility than DDTs (Takeoka et al. 1991), the input of HCHs from precipitation is also notable. In fact, due to their vapour pressure $\left(\mathrm{P}_{\mathrm{v}}\right.$ around $\left.4 \times 10^{-5} \mathrm{mmHg} / 25^{\circ} \mathrm{C}\right)$, $\mathrm{HCHs}$ can remain for a long time in the atmosphere and can be transported long distances, with the exception of $\beta-\mathrm{HCH}$, which has the lowest $P_{v}$ value and therefore does not evaporate easily (ATSDR 2005).

Some cyclodienes in the lake and catchment may also derive from atmospheric deposition. After the application of aldrin to soil, $50 \%$ is lost to the atmosphere after the first or second week. Aldrin accounted for around $8 \%$ of total pesticides both in the lake and the catchment. It has a relative high $P_{v}$ value $\left(1.2 \times 10^{-4} \mathrm{mmHg} / 25^{\circ} \mathrm{C}\right)$ and therefore shows a high tendency for volatilization. Dieldrin has a lower $P_{v}$ value $\left(5.89 \times 10^{-} 6 \mathrm{mmHg} / 25^{\circ} \mathrm{C}\right)$, so its tendency for volatilization is lower. Both non-polar compounds show very low solubility, so they are not present in high concentration in water $\left(\log \mathrm{K}_{\mathrm{ow}}\right.$ ca. 6$)$. They can travel long distances by attaching to dust particles (log Koc between 5.4 and 7.0; ATSDR 2002b).

In contrast, endrin does not volatilize readily due to its low $\mathrm{P}_{\mathrm{v}}\left(2 \times 10^{-7} \mathrm{mmHg} / 25^{\circ} \mathrm{C}\right)$. Similarly, the metabolites of endrin, i.e. endrin aldehyde and endrin ketone, are not readily scarce volatilized, $P_{v}$ being even lower than that of endrin, i.e. they would not be entering the lake or catchment by way of atmospheric deposition. They do not dissolve well in water and can therefore be detected at very low levels in this medium ( $\mathrm{K}_{\text {ow }}$ ca. 5); however, they are attached readily to soil particles (log $K_{\mathrm{oc}}$ between 4 and 5; ATSDR 1996).

There is a twofold explanation for the concentrations of OCPs in the lake sediments being higher than those in catchment soils: the lake collects substances from run-off and the atmosphere. In the dry season, an undetermined exportation occurs since dust swirls form and the reworking of pesticides is probably produced. On the other hand, although the lake is apparently pristine, it was used as a dumping area of agricultural or domestic wastes for years and has been cleaned only recently.

\section{Conclusions}

The concentration and distribution of 24 OCPs in the sediments of El Hito Lake and catchment were determined. The following were present in the lake at a concentration over the SSL values for human health and ecosystems: aldrin, endrin and $\gamma-\mathrm{HCH}$. Endosulfan (I + II) exceeded only ecosystem threshold, while $\alpha-\mathrm{HCH}$ and heptachlor epoxide B exceeded the threshold for human health (there are no SSLs for ecosystems for heptachlor epoxide B). The sediments from the southern half of the lake showed the highest concentrations of OCPs, with maxima that surpassed $200 \mu \mathrm{g} / \mathrm{kg}$, followed by the areas near to Montalbo village and El Hito village.

In the catchment, the following OCPs were present at a concentration over the SSL values for human health and ecosystems: $\gamma-\mathrm{HCH}$ (lindane), $\beta-\mathrm{HCH}$, and endrin. Heptachlor epoxide B exceeded the SSL only for human health and endosulfan $(\mathrm{I}+\mathrm{II})$ only for ecosystems. The highest concentration values, reaching $86 \mu \mathrm{g} / \mathrm{kg}$, were in the area of the lake, making it a receptor of contaminants, although other maxima were observed in the south of the catchment.

The OCPs in the sediments came mainly from the weathered agriculture soils and farms of the catchment, although a recent input was also inferred. The compounds reach the lake mainly through volatilization, a process by which they can be transported long distances and deposited with rainfall (HCHs, aldrin and dieldrin). Other OCPs (DDTs, endrin, endrin aldehyde and endrin ketone), which are not volatilized, attach to soil particles and are transported by wind and then deposited.

The distribution of OCPs in the lake and catchment is explained by the solubility of the compounds. In this regard, the more hydrophobic compounds were located in the southern part of the catchment, while the more hydrophilic ones were located in the lake area.

Therefore, we determined the concentration and distribution of OCPs in El Hito Lake - an area protected by several directives - and its catchment. Our results reveal clear diffuse contamination, in spite of the ban on OCPs some decades ago. This study can serve as a reference for environmental studies addressing other lakes and their catchments, especially when agriculture activities are developed in the area. Contaminants spilled in the catchment can reach the lake, thereby affecting the environment, in particular the fauna. In this regard, the pertinent authorities should define SSLs for the POPs that are not yet established and implement procedures through which to control the use of pesticides and insecticides in agricultural and livestock practices. 
Acknowledgements This work was supported by Empresa Nacional de Residuos Radiactivos (ENRESA) through Project P0079000214: "Estado Geoquímico y Evolución Ambiental de la Laguna de E1 Hito como Nivel de Referencia Ambiental del Entorno del ATC".

\section{References}

Agencia Estatal Boletín Oficial del Estado, BOE. (1976). https://www. boe.es/boe/dias/1976/05/21/pdfs/A09810-09811.pdf Accessed 1 Nov 2017.

Agencia Estatal Boletín Oficial del Estado, BOE. (1994). https://www. boe.es/boe/dias/1994/02/17/pdfs/A05132-05132.pdf Accessed 1 Nov 2017.

Agencia Estatal Boletín Oficial del Estado, BOE. (2013). http:// www.boe.es/boe/dias/2013/12/30/pdfs/BOE-A-2013-13757.pdf Accessed 1 Nov 2017.

Arienzo, M., Albanese, S., Lima, A., Cannatelli, C., Aliberti, F., Cicotti, F., et al. (2015). Assessment of the concentrations of polycyclic aromatic hydrocarbons and organochlorine pesticides in soils from the Sarno River basin, Italy, and ecotoxicological survey by Daphnia magna. Environmental Monitoring and Assessment, 187, 1-14. https://doi.org/10.1007/s 10661-015-4272-5.

ATSDR. (1996). Toxicological profile for endrin. U.S. Department of Health and Human Services. Public Health Service Agency for Toxic Substances and Disease Registry, Atlanta, Georgia.

ATSDR. (2002a). Toxicological profile for DDT, DDE and DDD. U.S. Department of Health and Human Services. Public Health Service Agency for Toxic Substances and Disease Registry, Atlanta, Georgia.

ATSDR. (2002b). Toxicological profile for aldrin and dieldrin. U.S. Department of Health and Human Services. Public Health Service Agency for Toxic Substances and Disease Registry, Atlanta, Georgia.

ATSDR. (2005). Toxicological profile for alpha-, beta-, gamma-, and delta-hexachlorocyclohexane. U.S. Department of Health and Human Services. Public Health Service Agency for Toxic Substances and Disease Registry, Atlanta, Georgia.

Bidleman, T. F., Jantunen, L. M. M., Helm, P. A., Brorstrom-Lunden, E., \& Juntto, S. (2002). Chlordane enantiomers and temporal trends of chlordane isomers in arctic air. Environmental Science and Technology, 36, 539-544.

Cirujano, S. (1995). Flora y vegetación de las lagunas y humedales de la provincia de Cuenca. Madrid: Junta de Comunidades de Castilla-La Mancha y Real Jardín Botánico, CSIC.

Cirujano, S., Medina, L., \& Chirino, M. (2002). Plantas acuáticas de las lagunas y humedales de Castilla-La Mancha. Madrid: Junta de Comunidades de Castilla-La Mancha y Real Jardín Botánico, CSIC.

Daly, G. L., Lei, Y. D., Muir, D. C. G., Castillo, L. E., \& Wania, F. (2007). Polycyclic aromatic hydrocarbons in Costa Rican air and soil: A tropical/temperate comparison. Atmospheric Environment, $41,7339-7350$.

Deinlein, M. (1998). When it comes to pesticides, birds are sitting ducks. Smithsonian's National Zoo \& Conservation Biology Institute. https://nationalzoo.si.edu/migratory-birds/news/when -it-comes-pesticides-birds-are-sitting-d. Accessed 22 Jan 2016.

Dirección General de Calidad y Evaluación Ambiental, Ministerio de Medio Ambiente. (2007). Guía Técnica de aplicación del RD $9 / 2005$, de 14 de enero, por el que se establece la relación de actividades potencialmente contaminantes del suelo y los criterios y estândares para la declaración de suelos contaminados. http:// www.mapama.gob.es/es/calidad-y-evaluacion-ambiental/temas/ sueloscontaminados/guia_tecnica_contaminantes_suelo_declarac ion_suelos_tcm7-3204.pdf. Accessed $10 \mathrm{Sep} 2015$.
Doong, R. A., Sun, Y. C., Liao, P. L., \& Peng, C. K. (2002). Distribution and fate of organochlorine pesticide residues in sediments from the selected rivers in Taiwan. Chemosphere, 48, 237-246.

El Nemr, A., Moneer, A. A., Khaled, A., \& El-Sikaily, A. (2012). Levels, distribution, and risk assessment of organochlorines in surficial sediments of the Red Sea coast, Egypt. Environmental Monitoring and Assessment, 185, 4835-4853.

E1-Naggar, N. A., Emara, H. I., Rifaat, A. E., Said, T. O., AbouShahba, R. M., Shaltout, N. A., et al. (2013). Some anthropogenic driven toxic pollutants in El-Mex Bay and its neighborhood, Alexandria, Egypt. World Applied Sciences Journal, 21, $1512-1520$.

EPA. (1998). Method 3545A pressurized fluid extraction (PFE) https:// www.epa.gov/sites/production/files/2015-06/documents/epa-3545 a.pdf Accessed 29 Nov 2014.

FAO. (2015). Prevention and disposal of obsolete pesticides. http:// www.fao.org/agriculture/crops/obsolete-pesticides/preventionand-disposal-of-obsolete-pesticides/en/. Accessed 16 Nov 2015.

Fernández, J., Arjol, M. A., \& Cacho, C. (2013). POP-contaminated sites from $\mathrm{HCH}$ production in Sabiñánigo, Spain. Environmental Science and Pollution Research, 20, 1937-1950.

Fry, D. M. (1995). Reproductive effects in birds exposed to pesticides and industrial chemicals. Environmental Health Perspectives, 103 , $165-171$.

Furness, R. W. (1993). Birds as monitors of pollutants. In R. W. Furness \& J. J. D. Greenwood (Eds.), Birds as monitors of environmental change (pp. 87-143). London: Chapman and Hall.

Gao, J., Zhou, H., Pan, G., Wang, J., \& Chen, B. (2013). Factors influencing the persistence of organochlorine pesticides in surface soil from the region around the Hongze Lake, China. Science of the Total Environment, 443, 7-13.

GESAMP. (1993). Impact of oil and related chemicals and wastes on the marine environment. Report Studies, 50, 1-180.

Gilman, A. P., Peakall, D. B., Hallett, D. J., Fox, G. A., \& Norstrom, R. J. (1979). Herring gulls (Larus argentatus) as monitors of contamination in the Great Lakes. In F. Peter, P. Timmins, \& D. Perry (Eds.), Animals as monitors of environmental pollution (pp. 280-289). Washington DC: National Academy of Sciences.

Gong, X., Qi, S., Wang, Y., Julia, E. B., \& Chunling, L. (2007). Historical contamination and sources of organochlorine pesticides in sediment cores from Quanzhou Bay, Southeast China. Marine Pollution Bulletin, 54, 1434-1440.

González, M. J., Fernández, M. A., \& Hernández, L. M. (1991). Levels of chlorinated insecticides, total PCBs and PCB congeners in Spanish gull eggs. Archives of Environmental Contamination and Toxicology, 20, 343-348.

Gouin, T., Mackay, D., Webster, E., \& Wania, F. (2000). Screening chemicals for persistence in the environment. Environmental Science and Technology, 34, 881-884.

Guitart, R., Clavero, R., Mateo, R., \& Martínez, M. (2005). Levels of persistent organochlorine residues in eggs of greater flamingos from the Guadalquivir marshes (Doñana), Spain. Journal of Environmental Science and Health, 40, 753-760.

Hitch, R. K., \& Day, H. R. (1992). Unusual persistence of DDT in some Western USA soils. Bulletin of Environmental Contamination and Toxicology, 48, 259-264.

Holder, J. (1986). Assessment of the carcinogenicity of dicofol (kelthane (trade name)), DDT, $D D E$, and $D D D$ (TDE). Washington DC: U.S. Environmental Protection Agency.

Hu, Y., Yuan, L., Qi, S., Liu, H., \& Xing, X. (2014). Contamination of organochlorine pesticides in water and sediments from a waterbird-inhabited lake, East Central China. Environmental Science and Pollution Research, 21, 9376-9384. https://doi.org/10.1007 /s11356-014-2831-x.

Huang, S., Qiao, M., Wang, H., \& Wang, Z. (2006). Organochlorinated pesticides in surface sediments of Meiliang Bay in Taihu Lake, 
China. Journal of Environmental Science and Health Part A, 41, 223-234.

James, R. R., McDonald, J. G., Symonik, D. M., Swackhamer, D. L., \& Hites, R. A. (2001). Volatilization of toxaphene from Lakes Michigan and Superior. Environmental Science and Technology, $35,3653-3660$.

Jiang, Y. F., Wang, X. T., Jia, Y., Wang, F., Wu, M. H., Sheng, G. Y., et al. (2009). Occurrence, distribution and possible sources of organochlorine pesticides in agricultural soil of Shanghai, China. Journal of Hazardous Materials, 170, 989-997.

Li, Y. F. (1999). Global technical hexachlorocyclohexanes age and its contamination consequences in environment from 1948 to 1997. Science of the Total Environment, 232, 123-160.

Liu, W. J., Chen, D., Liu, X. D., Zheng, X. Y., Yang, W., Westgate, J. N., et al. (2010). Transport of semi volatile organic compounds to the Tibetan Plateau: Spatial and temporal variation in air concentrations in mountainous Western Sichuan, China. Environmental Science and Technology, 44, 1559-1565.

Liu, W. X., He, W., Qin, N., Kong, X. Z., He, Q. S., Ouyang, H. L., et al. (2012). Residues, distributions, sources, and ecological risks of OCPs in the water from Lake Chaohu, China. The Scientific World Journal. https://doi.org/10.1100/2012/897697.

Liu, W. X., Li, Y., Zuo, Q., Liu, S. Z., \& Tao, S. (2008). Residual characteristics of HCHs and DDTs in surface soils from the western zone of Bohai Bay. Acta Scientiae Circumstantiae, 28, 142-149.

Luzardo, O. P., Ruiz-Suárez, N., Henríquez-Hernández, L. A., Valerón, P. F., Camacho, M., Zumbado, M., et al. (2014). Assessment of the exposure to organochlorine pesticides, PCBs and PAHs in six species of predatory birds of the Canary Islands, Spain. Science of the Total Environment, 472, 146-153. https://doi.org/10.1016 /j.scitotenv.2013.11.021.

Macdonald, R., Eisenreich, S., Bidleman, T., Dachs, J., Pacyna, J., Jones, K., et al. (2001). Case studies on persistence and long range transport of persistent organic pollutants. In G. M. Klecka \& D. Mackay (Eds.), Evaluation of persistence and long range transport of organic chemicals in the environment (pp. 245-314). Pensacola: SETAC Press.

Mackay, D., Shiu, W. Y., \& Ma, K. C. (1997). Illustrated handbook of physical-chemical properties of environmental fate of organic chemicals (Vol. V). Boca Raton: Lewis Publishers.

Madroño, A., González, C., \& Atienza, J. C. (2004). Libro rojo de las aves de España. Madrid: DGB (MIMAM) and SEO/BirdLife.

Mañosa, S., Mateo, R., \& Guitart, R. (2001). A review of the effects of agricultural and industrial contamination on the Ebro delta biota and wildlife. Environmental Monitoring and Assessment, $71,187-205$

Mateo, R., Gil, C., Badía-Vila, M., Guitart, R., Hernández-Matías, A., Sanpera, C., et al. (2004). Use of fatty acids to explain variability of organochlorine concentrations in eggs and plasma of common terns (Sterna hirundo). Ecotoxicology, 13, 545-554.

Metcalf, R. L. (1955). Bencenehexachloride. In R. L. Metcalf (Ed.), Organic insecticides, their chemistry and mode of action (pp. 213-227). New York: Wiley-Interscience.

Morales, L., Martrat, M. G., Olmos, J., Parera, J., Vicente, J., Bertolero, A., et al. (2012). Persistent Organic Pollutants in gull eggs of two species (Larus michahellis and Larus audouinit) from the Ebro delta Natural Park. Chemosphere, 88, 1306-1316.

Mullié, W. C., Massi, A., Focardi, S., \& Renzoni, A. (1992). Residue levels of organochlorines and mercury in cattle egret, Bubulcus ibis, eggs from the Faiyum Oasis, Egypt. Bulletin of Environmental Contamination and Toxicology, 48, 739-746.

Newton, I. (1995). The contribution of some recent research on birds to ecological understanding. Journal of Animal Ecology, 64, 675-696.

Palomo, L. J., \& Gisbert, J. (2002). Atlas de los Mamíferos terrestres de España. Madrid: DGCN-SECEM-SECEMU.
Pathak, R., Suke, S. G., Ahmed, R. S., Tripathi, A. K., Guleria, K., Sharma, C. S., et al. (2008). Endosulfan and other organochlorine pesticide residues in maternal and cord blood in North Indian population. Bulletin of Environmental Contamination and Toxicology, 81, 216-219.

Peakall, D. B. (1970). Pesticides and the reproduction of birds. Scienfific American, 222, 72-78.

Piqué, E., Mateo, R., Fernández-Fernández, D., \& Guitart, R. (2006). Persistent organochlorine residues in livers of six species of Ciconiiformes (aves) from Spain. Journal of Environmental Science and Health, 41, 671-679.

Qiu, X. H., Zhu, T., Yao, B., Hu, J. X., \& Hu, S. W. (2005). Contribution of dicofol to the current DDT pollution in China. Environmental Science and Technology, 39, 4385-4390.

RAIS (2015). The Risk Assessment Information System. https://rais .ornl.gov/cgi-bin/tools/TOX_search?select=chem_spef. Accesed 6 Oct 2015.

Rateliffe, D. A. (1970). Changes attributable to pesticides in egg breakage frequency and eggshell thickness in some british birds. Journal of Applied Ecology, 7, 67-115.

Rathore, H. S., \& Nollet, L. M. L. (2012). Pesticides: Evaluation of environmental pollution. Boca Raton: CRC Press.

Rotterdam Convention (2004). http://www.pic.int/ Accessed 20 Feb 2016.

Rudd, R. L., \& Herman, S. G. (1972). Toxic effect of pesticide residues on wildlife. In F. Matsumura (Ed.), Environmental toxicology of pesticides (pp. 471-485). New York: Academic Press.

Sanpera, C., Ruiz, X., Jover, L., Llorente, G., Jabeen, R., Muhammad, A., et al. (2003). Persistent organic pollutants in little egret eggs from selected wetlands in Pakistan. Archives of Environmental Contamination and Toxicology, 44, 360-368.

Sastre, A., Martínez, S., Jurado, A., \& Acaso, E. (2008). Geohidrología del humedal de El Hito (prov. de Cuenca), IX Simposio de Hidrogeología: Asociación Española de Hidrogeólogos (pp. 305-314).

Shetty, P. K., Mitra, J., Murthy, N. B. K., Namitha, K. K., Sovitha, K. N., \& Raghu, K. (2000). Biodegradation of cyclodiene insecticide endosulfan by Mucor thermohyalospora MTCC. Current Science, $79,1381-1383$.

Shunthirasingham, C., Mmereki, B. T., Masamba, W., Oyiliagu, C. E., Lei, Y. D., \& Wania, F. (2010). Fate of pesticides in the arid subtropics, Botswana, Southern Africa. Environmental Science and Technology, 44, 8082-8088.

Solomon, G. M., \& Weiss, P. M. (2002). Chemical contaminants in breast milk: Time trends and regional variability. Environmental Health Perspectives, 110, 339-347.

Stockholm Convention. (2001). Stockholm Convention on Persistent Organic Pollutant (POPs). http://chm.pops.int/. Accessed 10 Dec 2015.

Takeoka, H., Rarnesh, A., Iwata, H., Tanabe, S., Sobramanian, A. N., Mohan, D., et al. (1991). Fate of the insecticide HCH in the tropical coastal area of South India. Marine Pollution Bulletin, 22, 290-297.

van Leeuwen, C. J., \& Hermens, J. L. M. (1995). Risk assessment of chemicals: an introduction. Dordrecht: Springer Science and Business Media.

Walker, C. H. (1983). Pesticides and birds: Mechanisms of selective toxicity. Agriculture, Ecosystems \& Environment, 9, 211-226.

Wania, F. (2006). The potential of degradable organic chemicals for absolute and relative enrichment in the Arctic. Environmental Science and Technology, 40, 569-577.

Wania, F., \& Mackay, D. (1995). A global distribution model for persistent organic chemicals. Science of the Total Environment, 160-161, 211-232.

Wania, F., \& Mackay, D. (1999). The evolution of mass balance models of persistent organic pollutant fate in the environment. Environmental Pollution, 100, 223-240. 
Wania, F., Mackay, D., \& Li, Y. F. (1997). Persistent organic pollutants in the Arctic: identifying sources, quantifying pathways, and predicting trends. In: The AMAP International Symposium on Environmental Pollution in the Arctic, Tromsi, Extended Abstracts (pp. 24-27).

World Health Organization. (1984). Environmental health criteria 40: endosulfan. Geneva: World Health Organization.

Wu, W. Z., Xu, Y., Schramm, K. W., \& Kettrup, A. (1997). Study of sorption, biodegradation and isomerization of $\mathrm{HCH}$ in stimulated sediment water system. Chemosphere, 35, 1887-1894.

Yang, Y., Toor, G. S., \& Williams, C. F. (2015). Pharmaceuticals and organochlorine pesticides in sediments of an urban river in
Florida, USA. Journal of Soils and Sediments, 15(4), 993-1004. https://doi.org/10.1007/s11368-015-1077-7.

Yuan, L., Qi, S., Wu, X., Wu, C., Xing, X., \& Gong, X. (2013). Spatia and temporal variations of organochlorine pesticides (OCPs) in water and sediments from Honghu Lake, China. Journal of Geochemical Exploration, 132, 181-187.

Zhang, Z. L., Huang, J., Yu, G., \& Hong, H. (2004). Occurrence of PAHs, PCBs and organochlorine pesticides in Tonghui River of Beijing, China. Environmental Pollution, 130, 249-261.

Zhu, Y., Liu, H., Xi, Z., Cheng, H., \& Xu, X. (2005). Organochlorine pesticides (DDTs and $\mathrm{HCH}$ ) in soils from the outskirts of Beijing, China. Chemosphere, 60, 770-778.

\section{Affiliations}

\section{Yolanda Sánchez-Palencia ${ }^{1}$ D . José E. Ortiz ${ }^{1} \cdot$ Trinidad Torres $^{1}$. Juan Llamas ${ }^{1}$}

Yolanda Sánchez-Palencia

yolanda.sanchezpalencia@upm.es
1 Biomolecular Stratigraphy Laboratory, E.T.S.I. Minas y Energía, Universidad Politécnica de Madrid, Madrid 28003, Spain 